Article

\title{
Analysis of Possible Triggering Mechanisms of Severe Thunderstorms in the Tropical Central Andes of Peru, Mantaro Valley
}

\author{
Flores-Rojas, J.L. *D, Moya-Alvarez, A.S. (D), Kumar, S., Martinez-Castro, D., Villalobos-Puma, E. \\ and Silva-Vidal, $Y$. \\ Geophysical Institute of Perú, Calle Badajoz 169 Urb. Mayorazgo IV Etapa, Ate, Lima 15012, Peru; \\ amoya@igp.gob.pe (A.S.M.A.); skumar@igp.gob.pe (S.K.); dmartinez@igp.gob.pe (D.M.C.); \\ cah7@igp.gob.pe (E.V.P.); yamina.silva@igp.gob.pe (F.Y.S.V.) \\ * Correspondence: jflores@igp.gob.pe; Tel.: +51-924133957
}

Received: 10 May 2019; Accepted: 27 May 2019; Published: 1 June 2019

\begin{abstract}
The aim of the present study is to analyze the triggering mechanisms of three thunderstorms (TSs) associated with severe rainfall, hail and lightening in the tropical central Andes of Peru, specifically above the Huancayo observatory $\left(12.04^{\circ} \mathrm{S}, 75.32^{\circ} \mathrm{W}, 3313 \mathrm{~m}\right.$ a.s.l.) located in the Mantaro valley during the spring-summer season (2015-2016). For this purpose, we used a set of in-situ pluviometric observations, satellite remote sensing data, the Compact Meteorological Ka-Band Cloud Radar (MIRA-35C), the Boundary Layer Tropospheric Radar and downscaling model simulations with the Weather Research and Forecasting (WRF) Model (resolutions: $18 \mathrm{~km}, 6 \mathrm{~km}$ and $2 \mathrm{~km}$ ), and the Advance Regional Prediction System (ARPS) (resolution: $0.5 \mathrm{~km}$ ) models in order to analyze the dynamic of the atmosphere in the synoptic, meso and local scales processes that control the occurrence of the three TS events. The results show that at synoptic scale, the TSs are characterized by the southern displacement of the South-east Pacific Subtropical Anticyclone up to latitudes higher than $35^{\circ} \mathrm{S}$, by the weakening and south-eastern displacement of the Bolivian high-North east low system and by the intrusion of westerly winds along the west side of the central Andes at upper and medium levels of the atmosphere. At meso-scale, apparently, two important moisture fluxes from opposite directions are filtered through the passes along the Andes: one from the north-west and the other from the south-east directions converge and trigger the deep convection into the Mantaro valley. These moisture fluxes are generated by the intrusion of the sea-breeze from the Pacific ocean along the west of the Andes coupling with upper and middle westerly winds and by the thermally induced moisture fluxes coming from the South American low level jet at the east side of the Andes. At the local scale, there is a low-level conditional instability in the previous hours as well as during the occurrence of the TSs above the Huancayo observatory. In addition, the simulation results indicated the possibility of generation of inertial gravity waves in the Amazon basin, associated with geostrophic adjustment which transports energy and moisture into the central Andes plateau and consequently intensifies the thunderstorms above the Mantaro valley.
\end{abstract}

Keywords: thunderstorms; hailstorms; sea-breeze circulations; central andes; inertia gravity waves; model simulations 


\section{Introduction}

Cumulonimbus $(\mathrm{Cb})$ clouds are the building blocks of thunderstorms (TSs) that produce severe rainfall, wind gust, frequent lightening, and large hail on the surface. $\mathrm{Cb}$ clouds transport moisture efficiently, and sensible and latent heat fluxes into the upper troposphere and lower stratosphere. As a consequence, they play an important role in the global energy balance and the general circulation of the atmosphere [1]. Some of the most intense convective cloud systems on the planet are present in South America. It was identified that warm and moist air masses, required to generate deep convection east of the Andes Cordillera, are generally the result of moisture transported by the South America Low Level Jet (SALLJ) [2]. The presence of the tropical Andes Cordillera, which is a 3 to $7 \mathrm{~km}$ high north-south oriented mountain, acts like a wall which separates the low-level suppressed flow from the dry Pacific and the unstable and moist low-level flow of the Amazonian plains. The separation of both flows with different characteristics creates a strong zonal climatic gradient [3]. The influence of topography and surface wind flow on the characteristics of the precipitation over South America was investigated using the Global Precipitation Measurement Precipitation Radar (GPM-PR) data. The results show that the near surface wind flow transports the moisture from Amazon basin to the east flank of Andes. It has also been shown that the topography modulates the precipitation characteristics under different directional flow over and near the Andes [4].

The propagation of gravity waves (GWs) can influence the dynamical, transport and mixing properties of the atmosphere [5-7]. Due to their amplitudes and size, sometimes GWs are important in the development of deep convection [8]. In the Andes Cordillera region, by combining reanalysis data from the European Center for Medium-Range Weather Forecasts (ECMWF) and the National Center for Atmospheric Research NCEP—National Centers for Environmental Prediction (NCEP-NCAR), satellite and radio-soundings data with mesoscale WRF simulations were used to identify the major sources of inertia gravity waves (IGWs): the jet stream source, the convective source and the topographic source [9]. It was found that the vertical circulation in the entrance and exit region associated with the low-level jet (LLJ) results from the adjustment process in response to the imbalance caused by advection along the jet [10]. Under the conditionally unstable and nearly saturated atmosphere, the adjustment process can lead to an instability of the IGW, whose mechanism involves the positive feedback between the non-thermal wind and the vertical circulation [11].

In the northern foothills of the central Andes, the convection is probably triggered by the lifting of the SALLJ over the foothills. The lifted air mass from the SALLJ can be caused by the presence of passes along the Andes that generate mechanical channelization and thermally driven circulations of moisture fluxes along the valleys over the Andes [12]. By using observational data and modeling studies near La Paz (Bolivia), it was shown that some passes east of the Andes could contribute to channeling the moisture flux into the central Altiplano [13]. In a recent study [14], it was found that the relative maximum precipitation in the Northern Central Andes (NCA) highlands is mainly associated with the afternoon convergence of the following moisture fluxes: (1) a synoptic-scale north-westerly and south-easterly flows. The first one is associated with the synoptic SALLJ that penetrates in the Andes through the Apurimac valley region and the second one, coming mainly from the Bolivian Altiplano, is associated with the development of a regional cyclonic circulion centered in western Bolivia and (2) the presence of a local thermally-driven up-slope flow coming from the Pacific Ocean was also identified.

In the upper troposphere (200-300 hPa), the Bolivian high (BH) and the north-east low (NL) system are the main circulations over South America during the austral summer [15]. In the central Andes, the mid-level moisture transport from the Amazon and convection in the Andes has been associated with the regional upper level easterly winds (300-200 hPa) of the northern branch of the Bolivian high (BH) [16-19]. In this region, almost $80 \%$ of the total annual precipitation (350-400 mm) falls during the 
austral summer (December-March), when the strength of the BH generates mid and upper level up-slope easterly flow that causes the intrusion of a moist air influx from the Amazon basin onto the central Andes and feeds convective storms $[16,17,20]$.

Moreover, it was described that the existence of thermally driven surface up-slope flows in both the Pacific and the Amazon slopes of the Andes during the day, and the convergence of westerly and easterly moisture fluxes coming from the Pacific coast and the Amazon basin, respectively, generated afternoon precipitation events [16]. However, it was highlighted that it was not possible to clearly identify the relative contribution of local and regional circulation over the moisture flows because of the low resolution in time and space of the used reanalysis data and model simulations. For the Peruvian central Andes (Mantaro basin), it were identified wet and dry spells by using climatological low resolution data from NCEP-NCAR reanalysis data [19]. Dry spells were associated with a weakening of the BH-NL system, resulting in the suppression of moisture flux from the Amazon caused by westerly wind anomalies over the Peruvian Andes, while wet spells are characterized by a strengthened BH-NL system and easterly upper-air wind anomalies. Recently, a sensitivity analysis of parameterization schemes in WRF-ARW model on short and medium range precipitation forecast in the central Andes of Peru was performed. The conclusion was that Morrison for micro-physics and Grell-Freitas for convection is the best configuration for the whole analysis period [21].

In the Mantaro valley, the occurrence of severe TSs during the austral spring-summer season (September-March) have been reported [22]. These events are relatively sporadic but they generate a large amount of precipitation, hail and lightning. However, at the moment, there are not detailed studies of the main atmospheric processes that trigger these TSs in the Mantaro valley, specifically above the Huancayo observatory. Motivated by these considerations, we identified three of the most intense afternoon TSs measured by in-situ pluviometric data, estimated by remote sensing data from Global Precipitation Measurement (GPM) mission and estimated by cloud radar data from MIRA-35c in the period December 2015-November 2016. The TSs are characterized by their high intensity ( $>8 \mathrm{~mm}$ ), short duration (less than $3 \mathrm{~h}$ ) and spatial coverage around $20 \mathrm{~km}$. In addition, we analyzed the synoptic, meso and local scale processes and identified the main moisture sources of these TSs that generated abundant rainfall, hail and lightning above the Huancayo observatory using reanalysis data from Global Forecast System (GFS) and high resolution numerical simulations with WRF and ARPS models. Finally, we compared the atmospheric conditions during the occurrence of these TSs with the climatological conditions of dry and wet spells previously identified in the central Andes (Mantaro basin) [16,19].

The paper is organized as follows: In Section 2, we describe the characteristics of the Mantaro valley located in the central Andes of Peru. The procedure to calculate the water vapor flux from the model output variables in order to identify the moisture sources for the development of thunderstorms is described in Section 3.1. Section 3.2 describes the main characteristics of model simulations with WRF and ARPS models used to analyze the main features of the TSs. The methodology to examine the IGW through the wavelet analysis is described in Section 3.3. The main characteristics of cloud radar MIRA-35c and wind radar BLTR, which are used to identify the TSs that occurred in the Mantaro valley, are described in Sections 3.4 and 3.5 respectively. The main features of the observed data of the TSs are presented in Section 4.1. The simulation results that characterize the TSs at large, regional and local scales and the development of IGWs are analyzed in Section 4.2. The discussions of observed and simulation results are presented in Section 5. Finally, Section 6 presents some conclusions and an outlook for the development of future research. 


\section{Site and Location}

The weather station is placed in the Huancayo observatory of the "Instituto Geofísico del Perú", located at the center of the Mantaro basin (MB) $\left(12.04^{\circ} \mathrm{S}, 75.32^{\circ} \mathrm{W}, 3313 \mathrm{~m}\right.$ a.s.1.) (Figure 1a). The MB is located in the central Peruvian Andes $\left(10.57^{\circ} 3 \mathrm{~S}-13.58^{\circ} \mathrm{S}, 73.92^{\circ} \mathrm{W}-76.67^{\circ} \mathrm{W}\right)$ with an area close to $34,550 \mathrm{~km}^{2}$ (Figure 1a). Its altitudes range from 500 to $5350 \mathrm{~m}$ a.s.l. and its average altitude is $3800 \mathrm{~m}$ a.s.l. [19]. On average, for the entire valley, there is a marked seasonal variability in rainfall, with maximum recorded between January and March and minimum registered between June to July. It was found that $83 \%$ of the annual rainfall takes place between the months of October and April, of which $48 \%$ is distributed almost equally between the months of January, February, and March. The maximum precipitation climatology (1960-2002), close to $120 \mathrm{~mm}$, was found in February and the minimum, close to $10 \mathrm{~mm}$, was found in June [22].
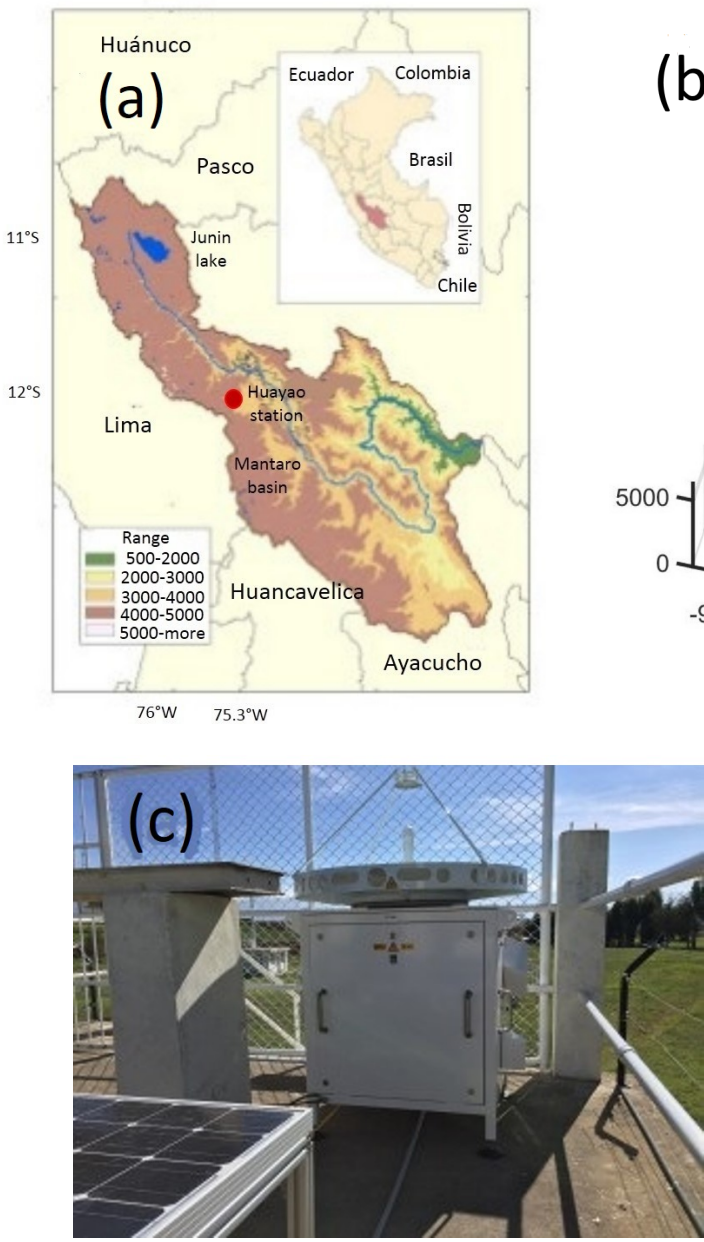
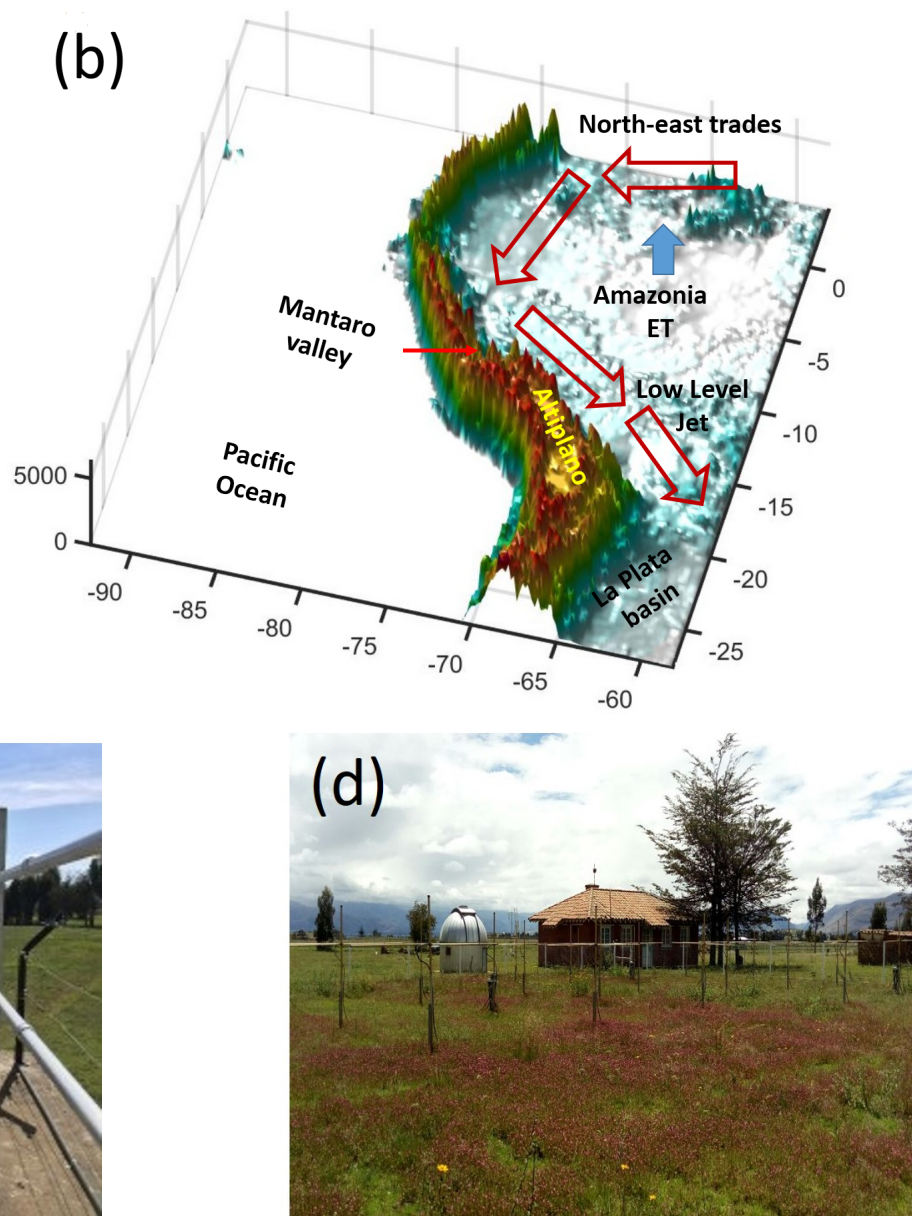

Figure 1. (a) The domain of the Mantaro valley and the location of the weather station in the Huancayo Observatory of the "Instituto Geofísico del Perú" (12.05 S, 75.32 W, 3313 m a.s.1.); (b) Conceptual model of the main components of the SALLJ system at east of the Andes cordillera. The location of the Mantaro valley at the north-west of the Altiplano is indicated; (c) Magnetron based pulsed Ka-Band Doppler radar MIRA-35c; (d) Boundary Layer and Troposphere Radar (BLTR). Both instruments have been installed in the Huancayo observatory since 2015. 
The average air temperature presents the lowest values in July and the maximum values in November. In the high areas of the basin (western end), it presents values around $4{ }^{\circ} \mathrm{C}$, in the Mantaro valley, between $8{ }^{\circ} \mathrm{C}$ and $10{ }^{\circ} \mathrm{C}$; in the central-southern sector of the basin, it reaches values between $12{ }^{\circ} \mathrm{C}$ and $16{ }^{\circ} \mathrm{C}$; in the eastern region, toward the mouth of the Mantaro river, it reaches $24{ }^{\circ} \mathrm{C}$ [22]. In the summer months, intense heating of the Earth's surface, due to large availability of solar energy, favors the development of convective clouds [23]. Moreover, the trade winds from the north-east intensify and transport moisture into the continent [24]. These winds cross the Amazon basin and rise to the Andes mountains, contributing to the formation of rainfall [25]. The Huancayo observatory is located in the Mantaro valley; consequently, it is under the influence of mountain-valley circulations as a result of thermal differences [26]. In the Mantaro valley, there have been reports of the occurrence of severe thunderstorms that produce severe rainfall, lightening, often severe wind gusts, and large hail during the austral spring-summer period (September-March). Besides their intensity, these thunderstorm events are characterized by their relatively short duration (few hours) within a dry period [22]. The methodology and data used to study these events are presented in Section 3.

\section{Methodology and Data}

\subsection{The Water Vapor Flux}

The amount of water vapor is an important factor that affects atmospheric energy, radiation, and generation-transport of latent heat. Its variability and anomalies determine drought and flood episodes; consequently, it also modulates basic elements of the regional climate [27]. However, the spatial and temporal variability of the atmospheric water vapor has been systematically explored only in the relatively reduced regions of South America $[27,28]$. In order to estimate the vertical integration of the moisture flux, we used an approximating continuous integral with finite differences based on the trapezoidal rule $[29,30]$. The calculation of moisture flux in pressure and altitude levels are performed as follows:

$$
\begin{aligned}
& \mathbf{F}=\frac{1}{g} \sum_{j=1}^{J} q_{j} \mathbf{u}_{j} \Delta p_{j} \\
& \mathbf{F}=\rho_{a} \sum_{j=1}^{J} q_{j} \mathbf{u}_{j} \Delta z_{j}
\end{aligned}
$$

where $J(=28$ or 43$)$ is the total number of levels, $g$ is the acceleration due to gravity, $\rho_{a}$ is the density of air, $q$ is the water vapor mixing ratio, $\mathbf{u}_{j}$ the horizontal wind vector of the jth layer layer, and $\Delta p_{j}$ and $\Delta z_{j}$ are the thickness in pressure and altitude of the jth layer, respectively. The WRF model uses pressure levels in the vertical. On the contrary, the ARPS model uses altitude levels. Thus, to consistently compare the various datasets, log-pressure altitudes are derived from pressure vertical coordinates using a scale height of $H=6.1 \mathrm{~km}$ and a reference of $p_{o}=1000 \mathrm{hPa}$ [9]. In some conditions, the transport of water vapor flux by the SALLJ can create the condition to generate inertia-gravity waves.

\subsection{Numerical Simulations}

For the present study we used the Weather Research and Forecasting Model (WRF 3.8) [31] and the Advance Regional Prediction System (ARPS 5.3.4) [32]. The one way interactive nesting Advanced Research WRF (ARW) core with Arakawa C-grid staggering and Runge-Kutta 3rd order time integration scheme was used in three nested domains over a region containing the central Andes and most of the west region of South America. The three domains selected with horizontal resolutions of $18 \mathrm{~km}(115 \times 140$ 
points $), 6 \mathrm{~km}(115 \times 140$ points $)$ and $2 \mathrm{~km}(127 \times 163$ points $)$ are centered over the Huancayo observatory located in the Mantaro valley $\left(12^{\circ} \mathrm{S}, 75.3^{\circ} \mathrm{W}\right.$ ) (Figure $2 \mathrm{a}$ ). For all domains were used 28 vertical and $90 \mathrm{~s}, 30 \mathrm{~s}$ and $10 \mathrm{~s}$ time steps, respectively. For constructing initial and boundary conditions of the simulations under the Lambert conformal map were used the $1^{\circ} \times 1^{\circ}$ NCEP Global Final Analysis (FNL) data. Lin microphysics scheme is used for the microphysical variable [33] in order to forecast the cloud, ice, snow, rain and hail mixing ratios. The Noah land-surface scheme $[34,35]$ was used for surface physics and the thermal diffusion process was used for the Monin-Obukhov [36]. The Grell-Freitas scheme was used for cumulus parameterization [37] for the first and second domains, while cumulus parameterization was set off for the inner domain. To represent the boundary-layer physics, the Yonsei University PBL [38] was used. For radiation processes, the Rapid Radiative Transfer Model Longwave (RRTM) [39] and the MM5 Dudhia Shortwave scheme were used.

In order to simulate the convective TSs with the proper high temporal and spatial resolution, the ARPS model was used in a single domain over a region comprising the Mantaro valley (Figure 2d). The domain has horizontal resolution of $0.5 \mathrm{~km}(147 \times 147)$ and 43 vertical levels of hyperbolic vertical grid starting at $80 \mathrm{~m}$ (bottom) and increasing up to an altitude of $20.5 \mathrm{~km}$ and a $4 \mathrm{~s}$ time step. To construct initial and boundary conditions of the simulations, we used the results of the inner domain (resolution: $2 \mathrm{~km}$ ), which were obtained with the WRF model under the Lambert conformal map. For the subgrid boundary layer, turbulence used a 1.5-order turbulent kinetic energy closure scheme [40]. For representing water phase change and precipitation processes, the micro-physical scheme of Schultz [41] was used. In addition, the ARPS model used the Global Ecosystems Database, which adapts bio-physical parameters such as albedo and emissivity, displacement height, leaf area index, fractional coverage, and roughness height. For analyzing each event, the simulations were initialized at 0000 UTC, ending at 0600 UTC of the next day $(30 \mathrm{~h})$, with a spin-up of $12 \mathrm{~h}$ for all domains.

\subsection{Wavelet Analysis of Igws}

The three dimensional nature of the IGW signatures allow the analysis along horizontal, vertical, or slanted direction. We analyzed horizontal latitude bands at standard low (200 hPa), medium (500 hPa), and high pressure $(850 \mathrm{hPa})$ levels. The model results at $18 \mathrm{~km}$ resolution available for outer domain of the simulations was sufficient for the typical horizontal wavelengths longer than $\lambda_{h}=100 \mathrm{~km}$ [42]. The identification and localization of main IGW modes can be done with a continuous wavelet theory (CWT). In general, unlike the vertical wavelengths $\lambda_{v}$ throughout the troposphere, the horizontal wavelengths $\lambda_{h}$ corresponding to each dominant mode were conserved and were not affected by refractions because of the background horizontal wind variation [43]. Some studies indicate that the vertical velocity $(w)$ consists of an appropriate variable to evidence the presence of IGW [44,45]. In order to analyze the dominant IGW modes, we considered the vertical velocity at the pressure level of $600 \mathrm{hPa}$ adjacent to the region with low gradient topographic around the Mantaro valley marked with the number 2 in Figure $2 f$. These were enclosed between $12.61^{\circ} \mathrm{S}$ and $12.59^{\circ} \mathrm{S}$. We look at these low gradient topographic regions because the model results show that the moisture fluxes intrude to the Andes plateau by the passes near to these regions. The average of $w$ consisted in a 86 data zonal profile (ZP) spaced in each inner first domain at $18 \mathrm{~km}$. In addition, we applied a high-pass filter with a cutoff at $700 \mathrm{~km}$ to $w$. Next, we subtracted filtered from not filtered ZPs to obtain $w^{\prime}$. The filter was applied again with a cutoff at $20 \mathrm{~km}$ to obtain a band-pass filtered $w_{b p}$ ZPs, retaining IGW modes with $20 \mathrm{~km}<\lambda_{h}<700 \mathrm{~km}$. Finally, a CWT procedure was applied to separate and locate the dominant spectral components. we3. 

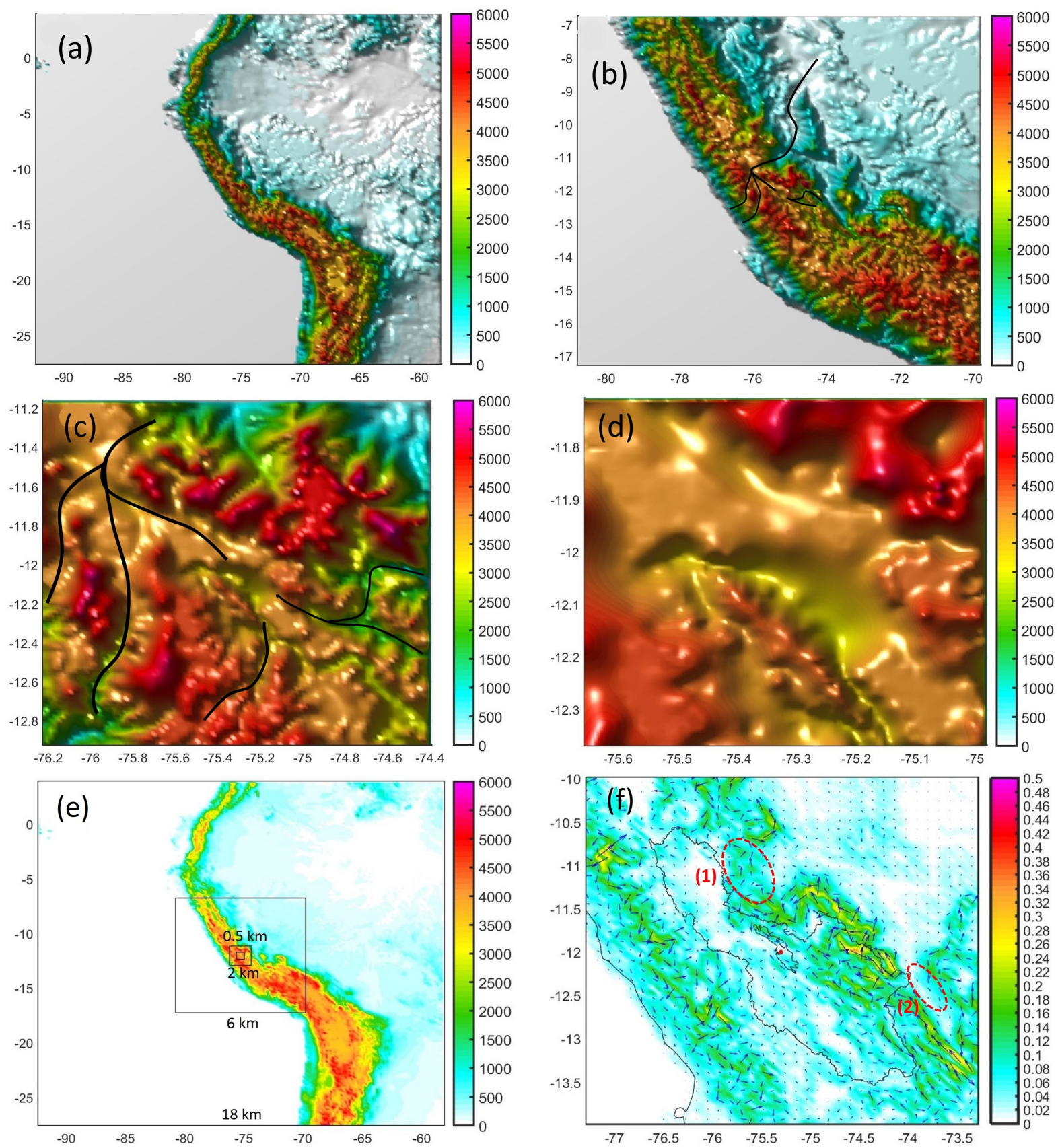

Figure 2. Domains and topography for the resolutions of (a) $18 \mathrm{~km}-\mathrm{WRF}$; (b) $6 \mathrm{~km}-\mathrm{WRF}$; (c) $2 \mathrm{~km}-\mathrm{WRF}$ and (d) $0.5 \mathrm{~km}$-ARPS. The colorbar indicates the altitude of topography in meters. The range of altitudes around the Mantaro valley is between $3000 \mathrm{~m}$ and $5500 \mathrm{~m}$. The black lines indicate the passes around the Mantaro valley; (e) Domains for model simulations and (f) local terrain slope for the resolution of $6 \mathrm{~km}$ around the Mantaro basin. Red dashed circles indicate regions of low topographic gradient (adimensional). Longitudes and latitudes are indicated.

\subsection{The Compact Meteorological Ka-Band Cloud Radar (Mira-35c)}

In order to identify the convective storm events on the Mantaro valley, we used the data obtained from Compact Meteorological Ka-Band Cloud Radar (MIRA-35c), installed at the Huancayo observatory 
(Figure 1a). MIRA-35c is a magnetron based pulsed Ka-Band Doppler radar with a very high sensitivity and allows detecting atmospheric clouds and fog (Figure 1c). The radar transmits linear polarized signal while co and cross polarized signals are received simultaneously to detect Doppler spectra of the reflectivity and the Linear De-polarization-Ratio (LDR). The reflectivity is used to determine the density of cloud constituents, while LDR helps to identify the target type [46]. MIRA-35c represents an effective means for cloud observation and bridges an observational gap in Earth's hydrological cycle by adequately detecting clouds and precipitation, and has been employed by a number of studies [47].

\subsection{The Boundary Layer and Troposphere Radar (Bltr)}

To analyze the wind patterns during the occurrence of the TSs, we used the Boundary Layer and Troposphere Radar (BLTR) which is installed at the Observatory of Huancayo $\left(12.05^{\circ} \mathrm{S}, 75.32^{\circ} \mathrm{W}\right.$, $3313 \mathrm{~m}$ a.s.l.). This radar is a wind profiler radar that operates in the VHF band approximately with a frequency of $50 \mathrm{MHz}$ (Figure 1d). The BLTR is a radar sensitive to winds and atmospheric turbulences where it captures the profile of neutral atmosphere winds at any given moment in time, allowing us to determine their evolution [48,49]. Likewise, at the operating frequency, it is not sensitive to cloud particles, but provides the three components of the wind (zonal, meridional and vertical) every minute.They operate in two modes: low and high modes. In the low mode, its resolution is $75 \mathrm{~m}$ with maximum height of $9 \mathrm{~km}$, with a resolution of $450 \mathrm{~m}$ and maximum height of $10 \mathrm{~km}$ in the high mode. For the present work we used the high resolution mode.

\subsection{Global Precipitation Measurement (Gpm), Goes Brightness Temperature and Reanalysis Data}

To identify the occurrence of TSs, we used surface rainfall estimations from the Global Precipitation Measurement (GPM) mission to build on the success of the Tropical Rainfall Measuring Mission (TRMM), which is a joint space mission between NASA and JAXA designed to monitor and study tropical and subtropical precipitation and the associated release of energy. The GPM is an international network of satellites that provides the next-generation global observations of rain and snow to advance our understanding of Earth's water and energy cycle and improve forecasting of extreme events. The GPM-IMERG product provides greater coverage between $65^{\circ} \mathrm{N}$ to $65^{\circ} \mathrm{S}$ and generates global rainfall estimations every $30 \mathrm{~min}$ at $0.1^{\circ}$ resolution. Initial comparative evaluations of GPM-IMERG data and other satellite-based precipitation products (TRMM-TMPA) against rainfall gauges under different climatic and topographic conditions have confirmed the expected improvements of GPM-IMERG in several topographic and climatic conditions as in China, Tibetan plateau, Iran, United States and slopes of the subtropical Andes [50-57].

A recent study performed a comparative ground validation of GPM-IMERG against a network of rain gauges in Ecuador and Peru over a 17-month period from April 2014 to August 2015 [58]. Results show that GPM-IMERG has a superior detection and quantitative rainfall intensity estimation ability than TMPA, particularly in the high Andes. When separating rainfall detection and rainfall rate estimation, the GPM-IMERG data shows better characterization of gauge observations. For the present study we used GPM-IMERG precipitation estimations to identify the three TSs above the Huancayo observatory. The rainfall estimations show a relatively good agreement in time and intensity with gauge data and model simulations which are presented in Section 4.1. For the present study, we used the GOES-8 visible $(0.62 \mu \mathrm{m}$; channel 1) and infrared $(10.7 \mu \mathrm{m}$; channel 4) imager data at 15-min intervals to estimate the brightness cloud temperatures during the occurrence of the TS1 event. The GOES-8 visible channel has improved image resolution over GOES-7 and improved signal to noise in the IR channels making it capable of resolving finer detail than its predecessors [59]. The data are processed at $1.0 \mathrm{~km}$ resolution for the visible (VIS) and $4.0 \mathrm{~km}$ resolution for the IR. In order to compare the results of WRF simulations at low 
resolution $(18 \mathrm{~km})$, we used the horizontal and vertical wind data from the third generation reanalysis product climate forecast system reanalysis (CFSR) provided by the National Centers for Environmental Prediction (NCEP) which is a global, high resolution (resolution: $0.5^{\circ}$ ) data.

\section{Results}

\subsection{Observed Data}

The first identified TS occurred on 29 December 2015 (TS1), the second on 7 January 2016 (TS2) and the third on 17 October 2016 (TS3). The time series of precipitation rate $\left(\mathrm{mm} \mathrm{h}^{-1}\right)$ estimated by in-situ pluviometer, GPM data and ARPS model simulation above the Huancayo observatory for the TS1, TS2 and TS3 events are shown in Figure 3a-c, respectively. High precipitation rates $\left(>8 \mathrm{~mm} \mathrm{~h}^{-1}\right)$ and relative short lifetime $(3 \mathrm{~h})$ were observed for all events. The time +interval for the TS1 event is approximately between 1830 and $2130 \mathrm{LT}$ with maximum peak close to $10 \mathrm{~mm} \mathrm{~h}^{-1}$ (gauge rainfall). For TS2 event is between 1630 and $1930 \mathrm{LT}$ with maximum peak close to $7 \mathrm{~mm} \mathrm{~h}^{-1}$ (gauge rainfall) and for TS3 event is between 1530 and 1830 LT with maximum peak close to $15 \mathrm{~mm} \mathrm{~h}^{-1}$ (GPM). For all events there exists a time delay between $30 \mathrm{~min}$ to $1 \mathrm{~h}$ between the different rainfall estimations and it was observed that during the hours before and after of the TSs, the amount of precipitation is practically zero. The intensity and lifetime of these rainfall estimations correspond to the characteristics of thunderstorm cell.

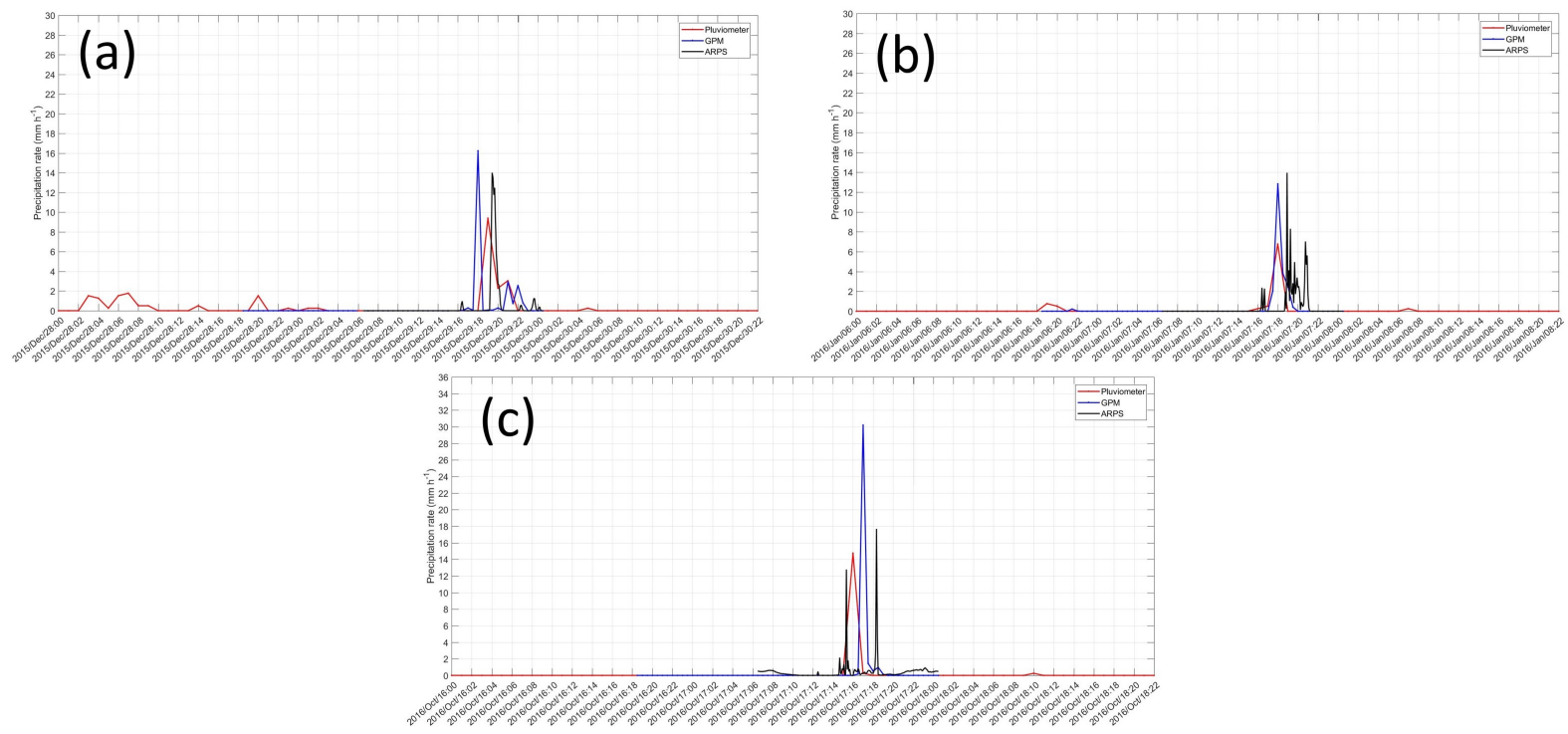

Figure 3. Time series of precipitation rate $\left(\mathrm{mm} \mathrm{h}^{-1}\right)$ above the Huancayo observatory obtained from in-situ pluviometer (red line), GPM (blue line) data and ARPS model (resolution: $0.5 \mathrm{~km}$ ) (black line) for (a) TS1; (b) TS2 and (c) TS3 events.

The spatial distribution of precipitation rate $\left(\mathrm{mm} \mathrm{h}^{-1}\right)$ estimated by GPM system for the TS1 at 1830 LT, TS2 at 1630 LT and TS3 at 1630 LT are shown in Figure 4a-c, respectively. For TS1 were observed two areas of high precipitation rate, the first one located north-west of the Huancayo observatory centered at $11.8^{\circ} \mathrm{S}$, $75.6^{\circ} \mathrm{W}$ and the second one close to the Huancayo observatory (Figure 3). These areas of high precipitation rate around the Mantaro valley indicate the presence of deep convection processes. Figure $5 \mathrm{a}-\mathrm{c}$ show the vertical sounding above the station of Rio Branco, Brazil $\left(10^{\circ} \mathrm{S}, 75.32^{\circ} \mathrm{W}\right)$ located in the Amazon basin for the TS1, TS2 and TS3 events, respectively. For all soundings are observed lower stable layers (1000-950 hPa) but above these layers, between the lifting condensation level (around $900 \mathrm{hPa}$ ) and the level 
of free convection (around $800 \mathrm{hPa}$ ) there exists an unsaturated level with conditional instability which could become unstable with externally imposed vertical motion. On the other hand, the maximum kinetic energy that a positively buoyant air parcel can acquire by ascending without exchanging momentum, heat and moisture with its environment is represented by the convective available potential energy (CAPE) and the threshold factor capable of preventing convection despite the existence of very high CAPE values is the convective inhibition energy (CIN). For all events, we used vertical sounding on a skew T-log $\mathrm{p}$ diagram on the station of Rio Branco-Brazil $\left(10^{\circ} \mathrm{S}, 67.80^{\circ} \mathrm{W}\right)$ at $12 \mathrm{Z}$ obtained from Wyoming University database. The CAPE presents high positive values (2192.1 J for TS1, 1536.7 J for TS2 and 1617.4 J for TS3) and the CIN low negative values ( $-28.1 \mathrm{~J}$ for TS1, $-8.9 \mathrm{~J}$ for TS2 and $-83.2 \mathrm{~J}$ for TS3).
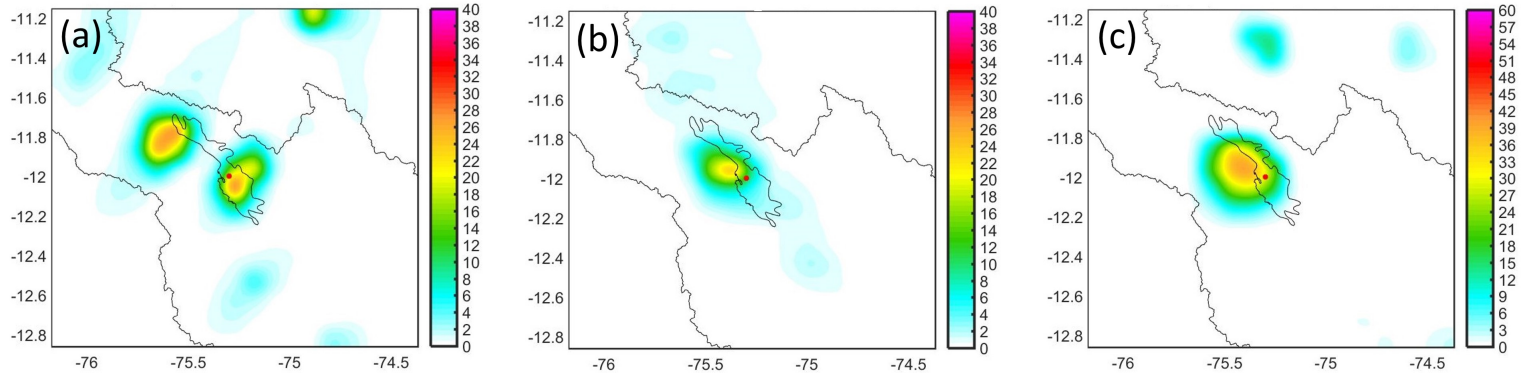

Figure 4. Spatial distribution of precipitation rate for the domain of $2 \mathrm{~km}$ (Figure 2d) from GPM data for (a) TS1 at 1830 LT; (b) TS2 at 1630 LT and (c) TS3 at 1630 LT. Longitudes, latitudes and contours of the Mantaro valley and Mantaro basin are indicated. The red circle indicates the position of the Huancayo observatory.
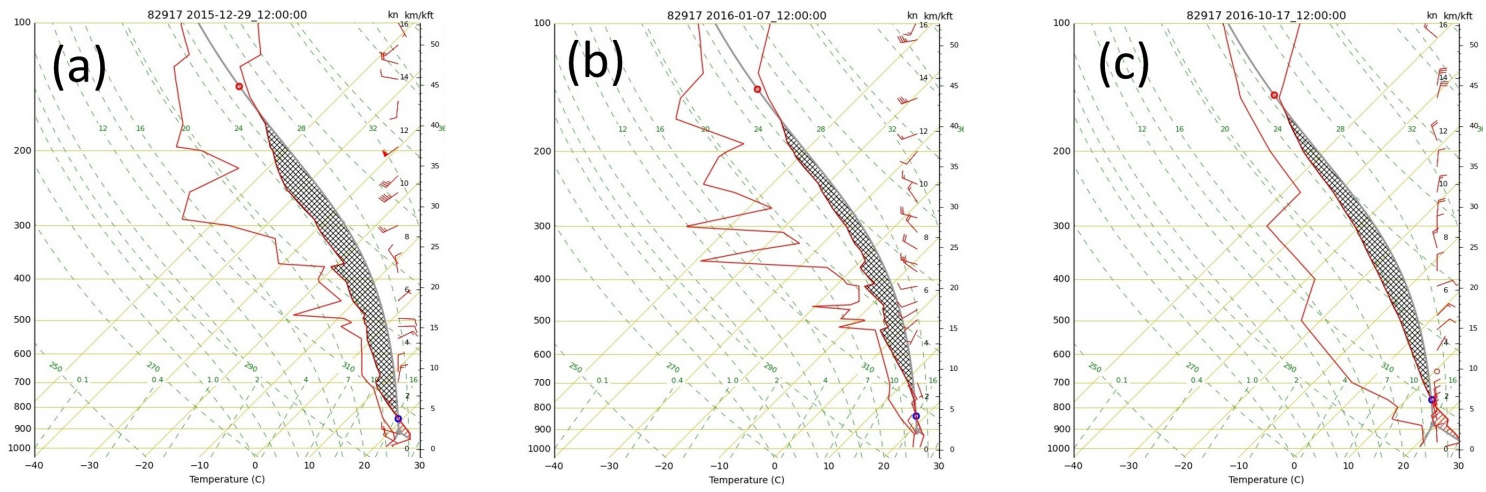

Figure 5. Vertical sounding on a skew T-log p diagram on the station of Rio Branco-Brazil $\left(10^{\circ} \mathrm{S}, 67.80^{\circ} \mathrm{W}\right)$ at $12 \mathrm{Z}$ (07 LT) for the (a) TS1; (b) TS2 and (c) TS3. The diagram shows the lifting condensation level, the free convection level and the level of neutral buoyancy.

Figure $6 \mathrm{a}-\mathrm{c}$ show the time series of reflectivity (dBZ) obtained from the Magnetron based cloud radar MIRA-35C above the Huancayo observatory for (a) TS1; (b) TS2 and (c) TS3 events. The magnetron based cloud radar (MIRA-35C) has higher sensitivity, a larger dynamic range and finer temporal-spatial resolution. However, the reflectivity data from MIRA-35C, working at $35 \mathrm{GHz}$ (ka-band), is usually significantly more attenuated than a centimeter-wavelength radar [60]. The intensities and areas of echoes are degraded and clouds or precipitation and attenuation is higher when the radar beam flows through a large number of hydrometeors. This situation is observed for all events. For the TS1 event, the radar data shows significant reflectivity values near the surface between 23 UTC (18 LT) to 02 UTC (21 LT) approximately. During this period, the reflectivity presents high values close to $40 \mathrm{DBZ}$ up to the first few kilometers above the surface, but for greater heights, the reflectivity drastically decreases its value by up 
to $-15 \mathrm{DBZ}$, which is an indication of the presence of a larger number of hydrometeors (rain and hail) that degrade the radar energy before it reaches storms further from the radar. For the TS2 and TS3 event, were observed significant reflectivity values between 20 UTC (15 LT) and 2300 UTC (18 LT), approximately.
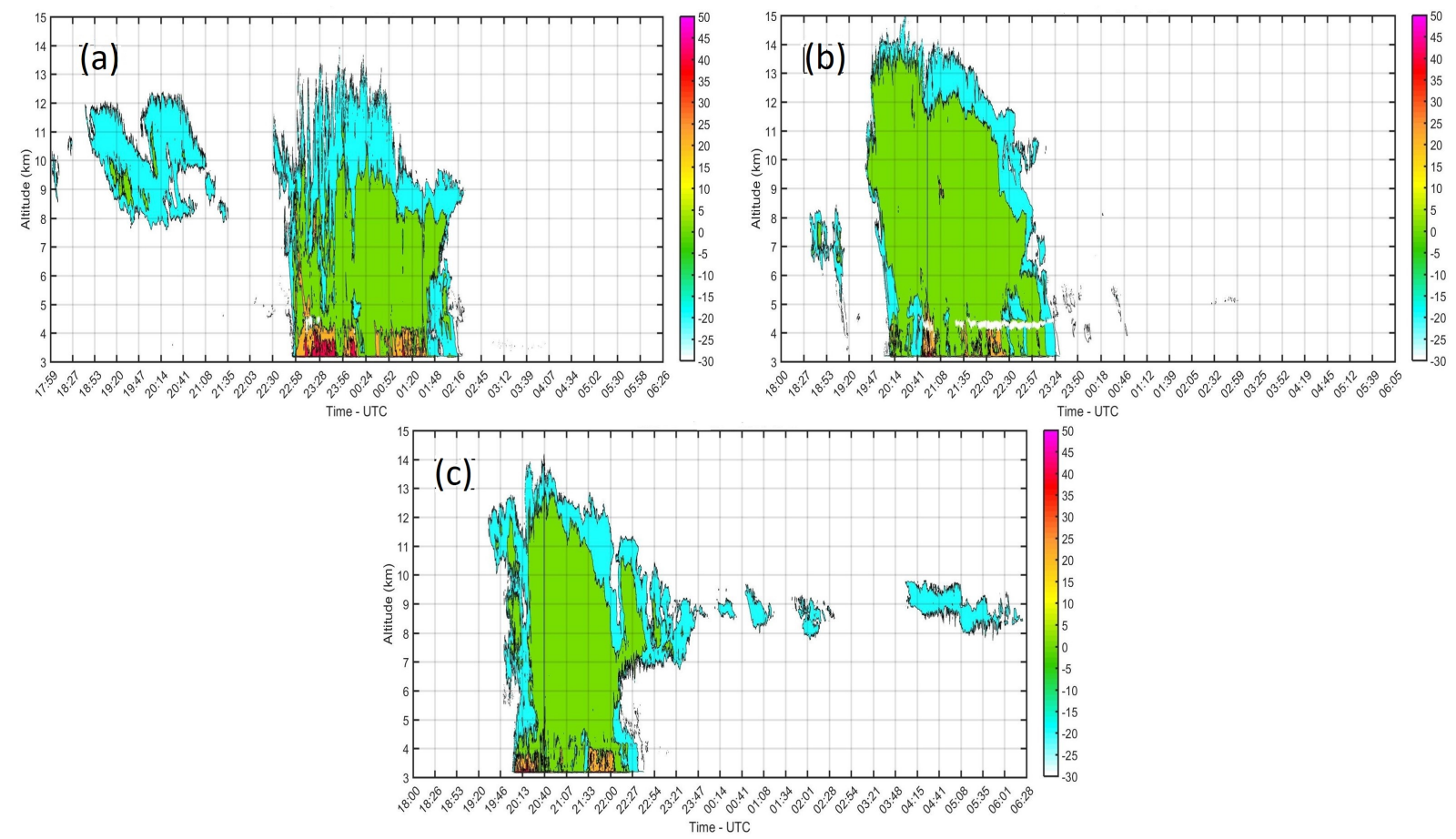

Figure 6. Time series (UTC-5) of reflectivity (dBZ) obtained from the Magnetron based cloud radar MIRA-35C above the Huancayo observatory for (a) TS1; (b) TS2 and (c) TS3 events.

\subsection{Simulation Results}

In this section, we analyzed the atmospheric processes for the three TSs that occurred above the Huancayo observatory in terms of large, meso and local scale circulations, and the moisture transport from medium to high resolution simulations obtained by the models WRF and ARPS.

\subsubsection{Large Scale Processes}

Figure $7 \mathrm{a}-\mathrm{c}$ show the wind streamlines and reduced pressure to sea level at 1800 UTC (1300 LT) obtained from the NCEP-NCAR reanalyses for the TS1, TS2 and TS3 events, respectively. For the TS1 event, it was observed that the South-east Pacific Subtropical Anticyclone (SPSA) is disturbed and weakened by a migratory cyclonic front located at $35^{\circ} \mathrm{S}$. Around the latitude of the Mantaro valley $\left(12^{\circ} \mathrm{S}\right)$, the surface wind flows south-easterly with a low atmospheric pressure close to $1010 \mathrm{hPa}$. For the TS2 and TS3 events it was observed a similar configuration, with the SPSA centered around $40^{\circ} \mathrm{S}$ and atmospheric pressure close to $1008 \mathrm{hPa}$ (TS2) and $1014 \mathrm{hPa}$ (TS3) around the latitude of the Mantaro valley (12 $\mathrm{S})$. Moreover, for all events a strong north westerly flow associated with the SALLJ was observed, which also exists in the level of $850 \mathrm{hPa}$ (not shown).

Figure $7 \mathrm{~d}-\mathrm{f}$ show the wind streamlines and vertical velocities at $300 \mathrm{hPa}$ obtained from the NCEP-NCAR reanalyses for the TS1, TS2 and TS3 events, respectively. For the TS1 event, the upper level circulation $(300 \mathrm{hPa})$ over the central Andes presents a strongly south-westerly circulation also observed at $200 \mathrm{hPa}$ (not shown). It is observed that the BH-NL system is displaced south-eastward with the center of the $\mathrm{BH}$ located at $20^{\circ} \mathrm{S}-54^{\circ} \mathrm{W}$. Apparently, this displacement of the $\mathrm{BH}$ is caused by the 
intrusion of the strong westerly circulations that form a cyclonic trough at $12^{\circ} \mathrm{S}-75^{\circ} \mathrm{W}$ (Figure $7 \mathrm{~d}$ ). For the TS2 event, the BH-NL system, that is not well configured, is displaced eastward with the BH centered around $15^{\circ} \mathrm{S}-55^{\circ} \mathrm{W}$. For the TS3 event, a well configured BH-NL system is displaced more eastward with the $\mathrm{BH}$ centered around $20^{\circ} \mathrm{S}-50^{\circ} \mathrm{W}$. For these events a strong westerly circulation along the Pacific Ocean also generates an eastward displacement of the BH-NL system and the NL looks like a trough across the Brazilian north-east region.
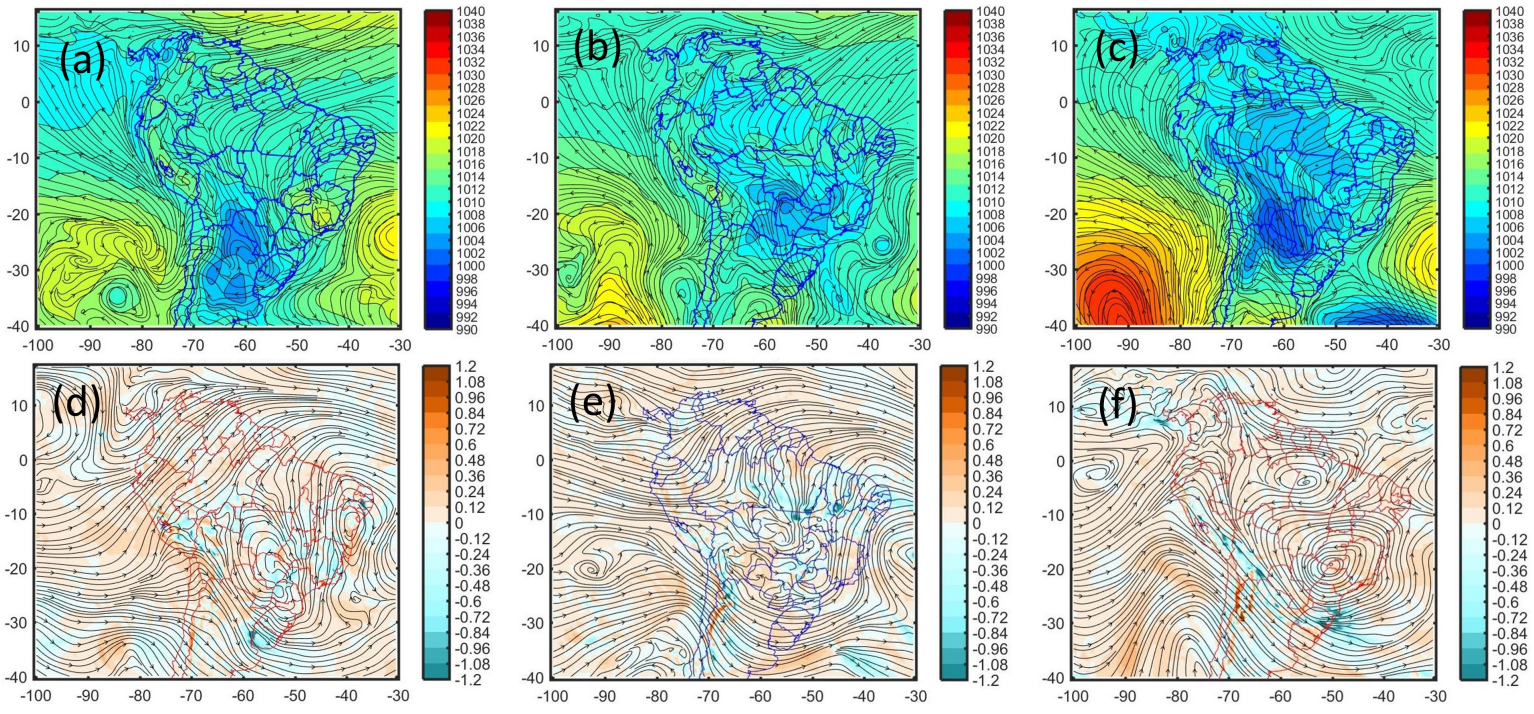

Figure 7. Composites of wind streamlines $\left(\mathrm{m} \mathrm{s}^{-1}\right)$ and reduced pressure to mean sea level (hPa) at 1800 UTC (13 LT) for (a) TS1; (b) TS2 and (c) TS3. Cold colors indicate lower values and warm colors higher values. Composites of wind streamlines $\left(\mathrm{m} \mathrm{s}^{-1}\right)$ and vertical velocities $\left(\mathrm{Pa} \mathrm{s}^{-1}\right)$ at $300 \mathrm{hPa}$ for (d) TS1; (e) TS2 and (f) TS3. Positive values indicate downdraft winds and negative values indicate updraft winds. All composites data were obtained from the NCEP-NCAR reanalyses (resolution: $0.5^{\circ}$ ).

\subsubsection{Regional Scale Processes}

For the TS1 at 1800 UTC (13 LT), Figure 8a shows the mean surface wind streamlines and combined iso-surfaces of cloud, ice, rain, and hail mixing ratios obtained with the WRF model (resolution $6 \mathrm{~km}$ ). The figure shows a well defined low level southeasterly circulation along the Pacific Ocean (west of the Andes). The simulation results show that the intrusion of the sea-breeze started at approximately 16 UTC (11 LT) along the Pacific coast of Peru. At 1800 UTC (13 LT), it was observed a large band of cloudiness at both sides of the Andes which is an evidence that the central Andes receives moisture generated by convection that develops along the mountain range. For the TS2 and TS3 events, a well defined low-level south-easterly circulation above the Pacific Ocean was also observed, but the intrusion of the sea breeze started at 15 UTC (10 LT) along the Pacific coast (not shown) earlier than the TS1 event.

Moreover, Figure $8 \mathrm{~b}$ shows the vertically integrated total column of water vapor flux obtained with the WRF model (resolution $6 \mathrm{~km}$ ) for the TS1 event at 18 UTC (13 LT) which covers the western central area of South America (Figure 2b). The simulation results show two main moisture regions at both sides of the Andes: (i) moisture transport by the SALLJ from north-west to south-east with the maximum close to $350 \mathrm{~kg} \mathrm{~m}^{-1} \mathrm{~s}^{-1}$ around the point $12^{\circ} \mathrm{S}-71^{\circ} \mathrm{W}$ located in the boundary with the Amazon basin, which is an area of heavy precipitation (hotspot) [61]. This moisture flux reaches values close to $200 \mathrm{~kg} \mathrm{~m}^{-1} \mathrm{~s}^{-1}$ around the eastern region of the Mantaro basin and (ii) moisture transport by the south-Pacific anticyclone from south-east to north-west with uniform values close to $175 \mathrm{~kg} \mathrm{~m}^{-1} \mathrm{~s}^{-1}$ around to the latitude of the Mantaro valley $\left(12^{\circ} \mathrm{S}\right)$. For the TS2 and TS3 events at 18 UTC (13 LT), there also exist two important 
moisture fluxes at the east side of the Andes associated with the SALLJ with values close to $150 \mathrm{~kg} \mathrm{~m}^{-1} \mathrm{~s}^{-1}$ and at the west side of the Andes associated with the south-Pacific anticyclone but with maximum values close to $100 \mathrm{~kg} \mathrm{~m}^{-1} \mathrm{~s}^{-1}$ around the latitude of the Mantaro valley.

Figure $8 \mathrm{c}$ shows the cross-section of meridional wind between $11.9^{\circ} \mathrm{S}$ and $12.1^{\circ} \mathrm{S}$ (Huancayo observatory) centered along the Mantaro valley and obtained with the WRF model (resolution: $6 \mathrm{~km}$ ) for the TS1 event at 18 UTC (13 LT). A well-defined negative meridional velocity was observed on the east side of the Andes between $75.5^{\circ} \mathrm{W}$ and $70^{\circ} \mathrm{W}$ which can be associated with the SALLJ. The meridional velocity reached negative values between -6 and $-8 \mathrm{~m} \mathrm{~s}^{-1}$ up to altitudes close to $4 \mathrm{~km}$ a.s.l. In this region, a strong vertical wind shear was observed with positive values close to $12 \mathrm{~m} \mathrm{~s}^{-1}$ between $6 \mathrm{~km}$ and $17 \mathrm{~km}$ approximately. These northward winds are associated with the strong south-westerly winds at high-levels (Figure 7d). At the west side of the Andes, the prevailing low-level winds with values close to $+8 \mathrm{~m} \mathrm{~s}^{-1}$ blow from the south-east along the Pacific coast up to altitudes close to $1 \mathrm{~km}$ a.s.l. A northerly jet with wind speeds close to $-4 \mathrm{~m} \mathrm{~s}^{-1}$ near the west of the Andes between $2 \mathrm{~km}$ and $5 \mathrm{~km}$ a.s.l. was also observed. This jet results from the mechanical blocking of the Andes upon the prevailing westerly wind in the middle troposphere [62,63]. At high-levels, a strongly northward flow above the Andes between $5 \mathrm{~km}$ a.s.l and $16 \mathrm{~km}$ a.s.l was observed with wind speeds close to $22 \mathrm{~m} \mathrm{~s}^{-1}$, which is associated with the strong south-westerly winds at $300 \mathrm{hPa}$ (Figure 7d).

A similar configuration is observed for the TS2 and TS3 events, across the latitude of the Mantaro valley, the meridional velocity associated with the SALLJ at the east side of the Andes presents lower negative values between -2 to $-4 \mathrm{~m} \mathrm{~s}^{-1}$ (TS2) and -2 to $-8 \mathrm{~m} \mathrm{~s}^{-1}$ (TS3) up to altitudes of $4 \mathrm{~km}$. At the west side of the Andes, there are positive velocities at the first levels of the atmosphere associated with the south-easterly circulation above the Pacific ocean with values close to $10 \mathrm{~m} \mathrm{~s}^{-1}$. At higher levels (300 to $200 \mathrm{hPa}$ ), there are negative velocities with values close to $-4 \mathrm{~m} \mathrm{~s}^{-1}$ (TS2) and $-8 \mathrm{~m} \mathrm{~s}^{-1}$ (TS3) associated with north-westerly circulations (Figure 7e,f).

On the other hand, the topography affects the movement of the airflow and the interaction between them depends on the properties of the airflow and on the dimensional characteristics of the topographic barrier [64]. In this context, Figure $2 \mathrm{f}$ shows the local terrain slope around the Mantaro basin for a resolution of $6 \mathrm{~km}$, where two well defined regions of gentle slopes at the east side of the Andes were observed. The first one is located at the north-eastern region $\left(11^{\circ} \mathrm{S}, 75.5^{\circ} \mathrm{W}\right)$ and the second one at the south-eastern region $\left(12.5^{\circ} \mathrm{S}, 73.8^{\circ} \mathrm{W}\right)$ of the Mantaro basin. Both regions have low slope values close to 0.08 , in comparison with higher values close to 0.3 in the central east regions of the Andes. At the west of the Andes, several regions of gentle slopes with values close to 0.08 are also observed. In general, air masses from the SALLJ flow more readily over these gentle slopes than locally steep ones. Moreover, Figure $2 b$,c, show the topography for the resolutions of 6 and $2 \mathrm{~km}$, respectively. The black lines highlight the presence of several passes around the Mantaro valley at the east and west sides of the Andes cordillera. At the east side can be observed two passes, centered at $11.3^{\circ} \mathrm{S}, 75.7^{\circ} \mathrm{W}$ and $12.2^{\circ} \mathrm{S}, 74.8^{\circ} \mathrm{W}$, respectively. At the west side, two passes centered at $12.5^{\circ} \mathrm{S}, 77^{\circ} \mathrm{W}$ and $12.8^{\circ} \mathrm{S}, 76^{\circ} \mathrm{W}$, respectively, can also be observed. These low passes lead to an elevated plateau around the Mantaro valley (Figure $2 \mathrm{~d}$ ).

An indication that these thermal circulations can contribute to the moisture transport from the SALLJ to the plateau around the Mantaro valley is observed in Figure 8b, which shows the horizontal flow of vertically integrated total column of water vapor flux for the convective event TS1 at 1800 UTC (domain: $6 \mathrm{~km}$ ). Some moisture fluxes along the passes are observed at the north-east and south-east of the Mantaro valley (Figure $2 b$ ). These moisture fluxes are better represented in the inner simulation (domain: $2 \mathrm{~km}$ ) (Figure 9a) where strong moisture fluxes are observed with values close to $100 \mathrm{~kg} \mathrm{~m}^{-1} \mathrm{~s}^{-1}$ at 1500 UTC (10 LT) across the passes highlighted in Figure 2c. The presence of an anticyclone circulation at the level of $600 \mathrm{hPa}$ (not shown) reinforces easterly winds at the level of the plateau. At $1800 \mathrm{UTC}$ (13 LT), the moisture flux at the north of the Mantaro valley is deflected and intensified eastward apparently by 
the intrusion of westerly moisture fluxes coming from the coupling between the sea-breeze circulation (Figure 8a) and the high and mid-level westerly winds (Figure 7d). The intrusion of the sea breeze at the west side of the Andes generates orographic deep convection that produces convective clouds, as it is observed in Figure $9 \mathrm{c}$ which shows the combined issosurface of cloud, ice, rain, and hail mixing ratios $\left(0.5 \mathrm{~g} \mathrm{~kg}^{-1}\right)$.

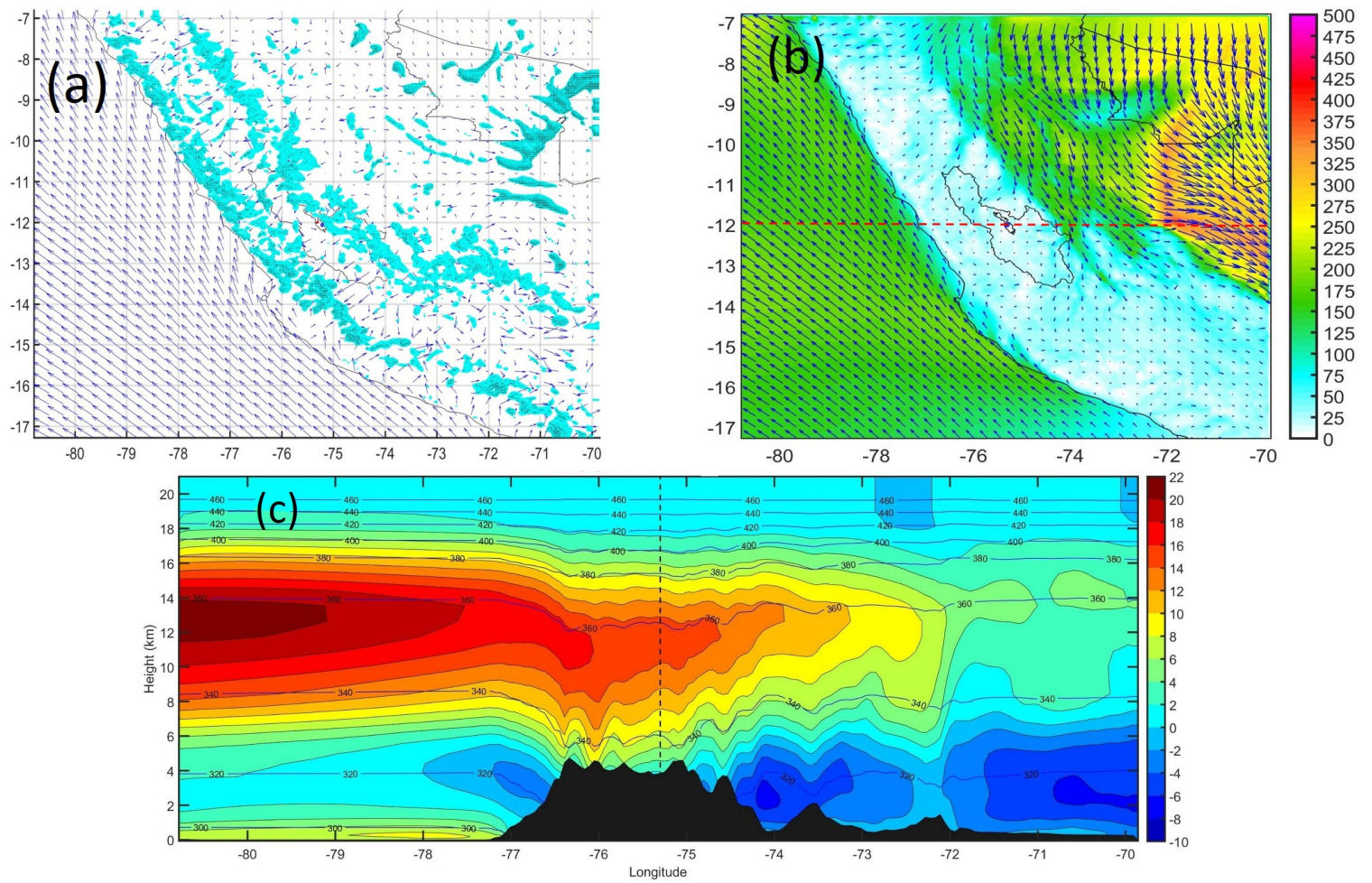

Figure 8. (a) Horizontal flow of surface wind $\left(\mathrm{m} \mathrm{s}^{-1}\right)$ and combined issosurface of cloud, ice, rain and hail mixing ratios $\left(q_{c}+q_{i}+q_{h}+q_{s}\right)\left(0.5 \mathrm{~g} \mathrm{~kg}^{-1}\right)$; (b) Horizontal flow of vertically integrated total column of water vapor flux $\left(\mathrm{kg} \mathrm{m}^{-1} \mathrm{~s}^{-1}\right)$ over the central region of South America. The red lines indicate latitudes for the mean of vertical cross section. The geographic boundaries of the Mantaro basin and the Mantaro valley are indicated; (c) Vertical cross section of mean average meridional velocity $\left(\mathrm{m} \mathrm{s}^{-1}\right)$ between $11.9^{\circ} \mathrm{S}$ and $12.1^{\circ} \mathrm{S}$. All fields were obtained from the WRF model (resolution: $18 \mathrm{~km}(\mathbf{a}, \mathbf{b})$ and $\left.6 \mathrm{~km}(\mathbf{c})\right)$ for the convective event TS1 at 18 UTC (13 LT) centered above the Huancayo observatory, which is highlighted with a dotted vertical line.

Later on, around 23 UTC (18 LT), the combined moisture flux flowed along the direction of the Mantaro basin with values close to $40 \mathrm{~kg} \mathrm{~m}^{-1} \mathrm{~s}^{-1}$ and collided with another apparently thermally induced south-easterly moisture flux coming from the Amazon basin with values close to $30 \mathrm{~kg} \mathrm{~m}^{-1} \mathrm{~s}^{-1}$, generating a convergence of water vapor flux 01 UTC (20 LT) (Figure 9c). The convergence of both moisture fluxes generates a strong deep convection in the center of the Mantaro valley close to the location the Huancayo observatory. This deep convection produces storm $\mathrm{Cb}$ clouds which propagate north-eastward as it was observed in Figure 9f, which shows the combined issosurface of cloud, ice, rain, and hail mixing ratios $\left(0.5 \mathrm{~g} \mathrm{~kg}^{-1}\right)$ at $0115 \mathrm{UTC}(2015 \mathrm{LT})$. In addition, the surface wind vectors associated with the strong convection over the center of the Mantaro valley are shown. Figure 10a shows the simulated cold temperatures of the top of $\mathrm{Cb}$ clouds over the center of the Mantaro valley which are similar to the patterns observed by the GOES satellite (Figure 10b), except at the north-east of the Huancayo observatory where 
the model does not generate clouds. After the intrusion of the moisture flux coming from the sea-breeze circulation, the moisture flux coming from the SALLJ returns to its initial state (Figure 9a) at approximately 03 UTC (22 LT) of the next day.
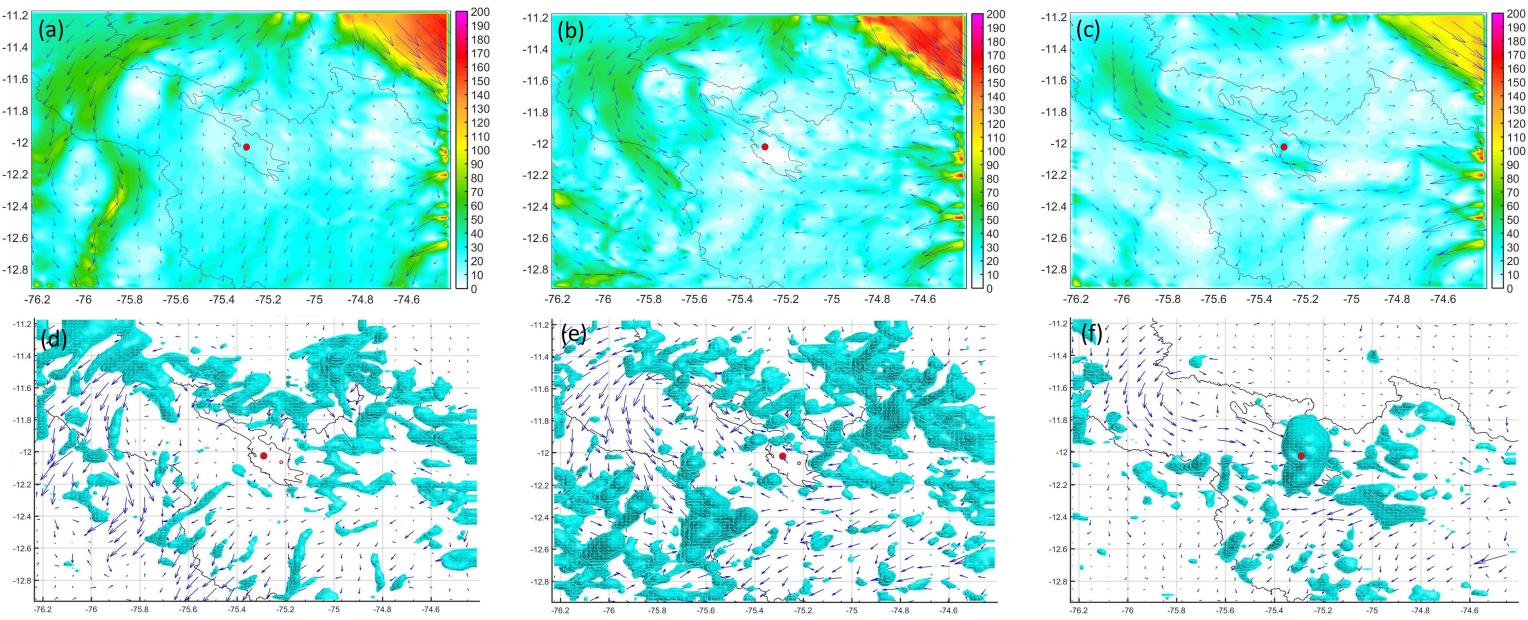

Figure 9. Horizontal flow of vertically integrated total column of water vapor flux $\left(\mathrm{kg} \mathrm{m}^{-1} \mathrm{~s}^{-1}\right)$ around the Mantaro basin at (a) 15 UTC (10 LT); (b) 18 UTC (13 LT) and (c) 01 UTC (20 LT). Horizontal flow of surface wind $\left(\mathrm{m} \mathrm{s}^{-1}\right)$ with combined issosurface of cloud, ice, rain and hail mixing ratios $\left(q_{c}+q_{i}+q_{c}+q_{h}+\right.$ $\left.q_{s}\right)\left(0.5 \mathrm{~g} \mathrm{~kg}^{-1}\right)$ over the Mantaro basin at (d) 15 UTC (10 LT); (e) 18 UTC (13 LT) and (f) 01 UTC (20 LT). All fields were obtained from the WRF model (resolution: $2 \mathrm{~km}$ ) for the convective event TS1. The full red circle indicates the location of the Huancayo observatory.

For the TS2 and TS3 events, a channeling process of moisture flux from the SALLJ by the passes into the plateau around the Mantaro valley was also observed. The vertically integrated vapor flux for the domain of $2 \mathrm{~km}$ shows moisture fluxes with values close to $70 \mathrm{~kg} \mathrm{~m}^{-1} \mathrm{~s}^{-1}$ (TS2) and $100 \mathrm{~kg} \mathrm{~m}^{-1} \mathrm{~s}^{-1}$ (TS3) at 15 UTC (10 LT) along the passes highlighted in Figure 2c. For both events the presence of an anticyclone circulation at $600 \mathrm{hPa}$ at the east side of the Andes is also observed. This circulation reinforces easterly winds at the level of the Mantaro basin. As in the previous event (TS1), at 17 UTC (12 LT), for both events, the moisture flux coming from the SALLJ is deflected and intensified eastward by the intrusion of the moisture fluxes coming from the coupling between the sea-breeze circulation and the high and mid level north-westerly winds.

Later on, at 22 UTC (17 LT), the combined moisture flux flowed along the direction of the Mantaro basin with values close to $90 \mathrm{~kg} \mathrm{~m}^{-1} \mathrm{~s}^{-1}$ (TS2) and $120 \mathrm{~kg} \mathrm{~m}^{-1} \mathrm{~s}^{-1}$ (TS3) and collided with another apparently thermally induced south-easterly moisture flux coming from the Amazon basin with values close to $10 \mathrm{~kg} \mathrm{~m}^{-1} \mathrm{~s}^{-1}$, generating a convergence of water vapor flux at $00 \mathrm{UTC}$ (19 LT). The convergence of both moisture fluxes generates a deep convection in the center of the Mantaro valley close to the location of the Huancayo observatory but that is weaker than the event TS1, because of the less intense south-easterly moisture flux. For both events (TS2 and TS3), after the intrusion of the moisture flux coming from the sea-breeze circulation, the moisture flux coming from the SALLJ returns to its initial state at approximately 06 UTC (01 LT) of the next day (not shown). 

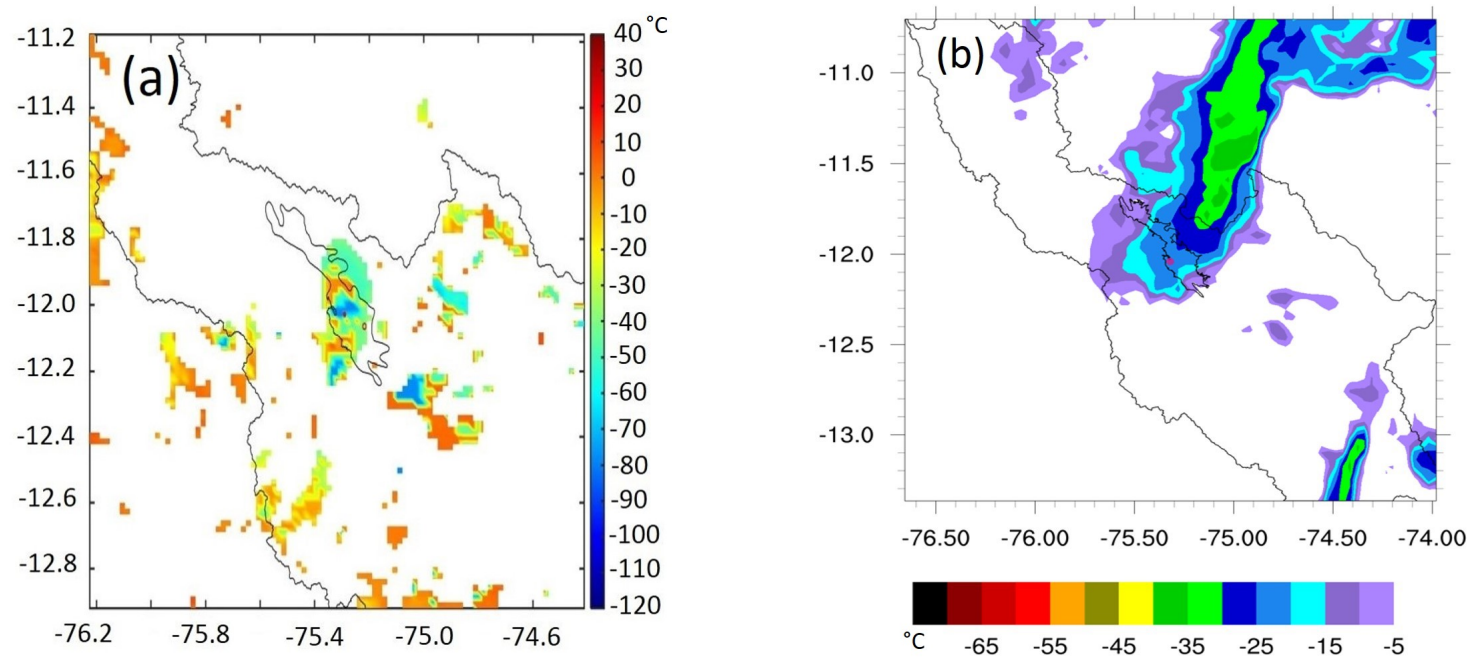

Figure 10. (a) Patterns of top cloud temperature obtained from the WRF model (resolution: $6 \mathrm{~km}$ ) at 01 UTC (20 LT); (b) Patterns of cloud brightness temperature around the Mantaro valley from GOES at 01 UTC (20 LT). The geographic boundaries of the Mantaro basin and the Mantaro valley are indicated.

\subsubsection{Inertial Gravity Waves}

Some studies have reported intense low-frequency gravity wave activity in jet exit regions upstream of an upper level ridge $[65,66]$ and trough [67]. These conditions are presented in the convective event TS1. Figure 11a shows a strong upper level jet $(300 \mathrm{hPa})$ associated with the intrusion of a trough around the station of Rio Branco-Brazil $\left(10.0^{\circ} \mathrm{S}, 67.80^{\circ} \mathrm{W}\right)$, and Figure $11 \mathrm{~b}$ shows a warm and moist low level jet associated with the SALLJ for the convective event TS1 at 15 UTC (10 LT). In this atmospheric configuration, both the cold air advection at upper levels and its superposition with warm and moist air advection at the low level could have an important effect on the generation of the potential energy that maintains an unstable IGW. If the interaction associated with the jet stream between the advection and adjustment processes occurs in the region, which is conditionally unstable and where the air is nearly saturated, there occurs a development of non-thermal wind and vertical circulation which generates an unstable IGW [54].

Figure 11d shows the vertical sounding on the station of Rio Branco, Brazil, which presents a conditionally unstable atmosphere. A strong inversion in the lower layer (1000-950 hPa) is observed; consequently, this layer is stable. Above this layer, between the lifting condensation level (LCL: 915.2 hPa) and the level of free convection (LFC: $850.9 \mathrm{hPa}$ ), there exists a layer with conditional instability which is unsaturated, but could became unstable with externally imposed vertical motion to bring a parcel in this layer to its LFC. Furthermore, the development of vertical circulation is observed in Figure 11c which shows the vertical cross-section of mean vertical wind speed along the longitude, between $11.98^{\circ} \mathrm{S}$ to $12.02^{\circ} \mathrm{S}$, obtained from the model WRF (resolution: $18 \mathrm{~km}$ ) for the convective event TS1 at 15 UTC (10 LT). The vertical velocity associated with the development of the IGW reaches values between $\pm 0.3 \mathrm{~m} \mathrm{~s}^{-1}$. In addition, the deep of the IGW between 1-20 km height is observed, with maximum intensity of vertical velocity at $8 \mathrm{~km}(260 \mathrm{hPa})$ approximately. In general, the maximum kinetic energy that a positively buoyant parcel can acquire by ascending without exchanging momentum, heat and moisture with its environment is represented by the convective available potential energy (CAPE) and the convective inhibition energy (CIN) [54]. The latter describes a threshold factor capable of preventing convection despite the existence of very high CAPE values. For the station of Rio Branco, Brazil, around the region where the IGW develops, 
the CAPE presents a high value $\left(2192 \mathrm{~J} \mathrm{~kg}^{-1}\right)$, and the convective inhibition energy (CIN) presents a very low value $\left(-28 \mathrm{~J} \mathrm{~kg}^{-1}\right)$.
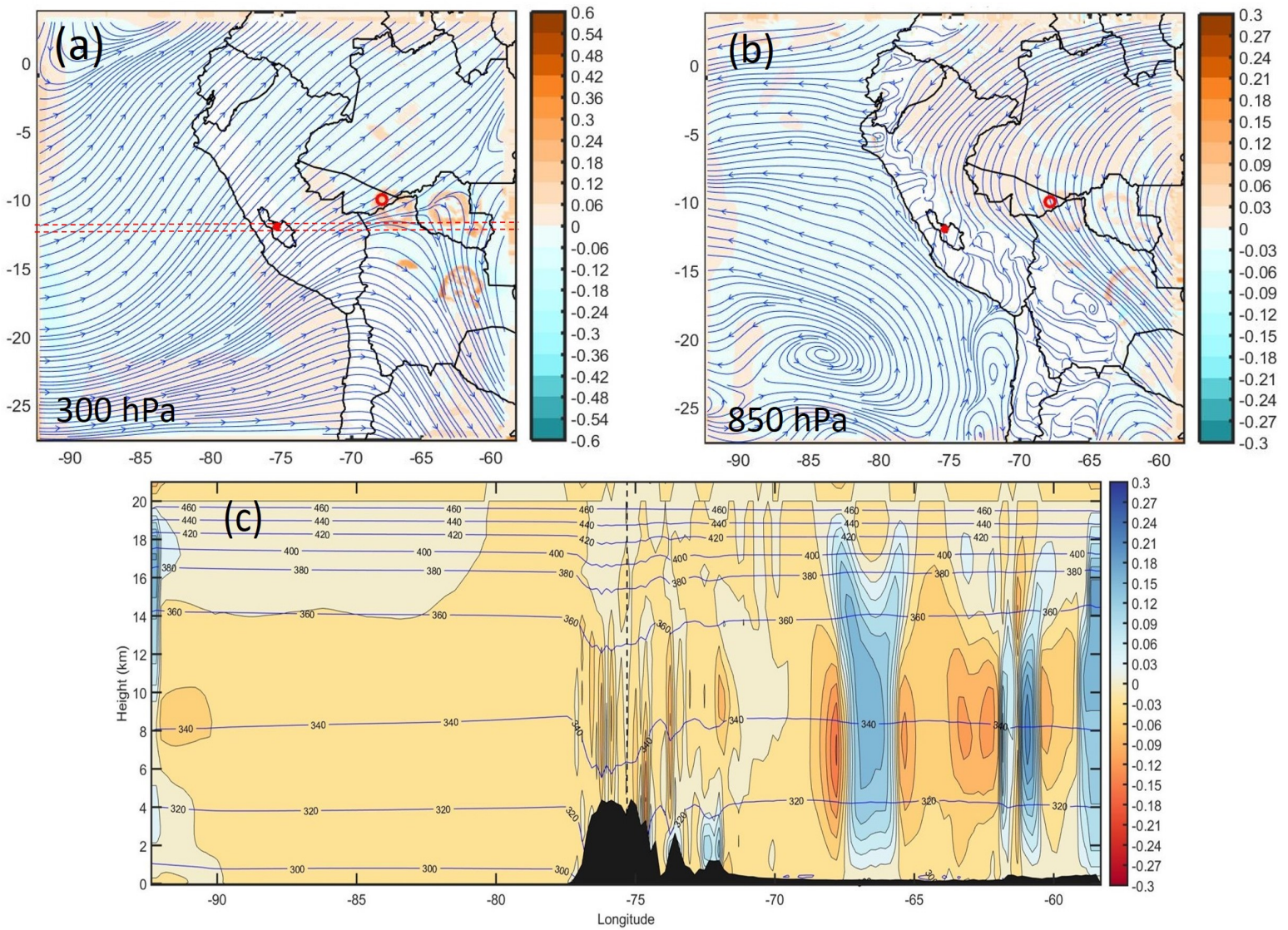

Figure 11. Composites of horizontal wind streamlines $\left(\mathrm{m} \mathrm{s}^{-1}\right)$ and vertical wind speed $\left(\mathrm{m} \mathrm{s}^{-1}\right)$ at $(\mathbf{a}) 300 \mathrm{hPa}$ and (b) $850 \mathrm{hPa}$; (c) Vertical cross-section of mean vertical wind speed ( $\mathrm{m} \mathrm{s}^{-1}$ ) along the longitude, between $11.98^{\circ} \mathrm{S}$ to $12.02^{\circ} \mathrm{S}$. The composite data were obtained from the model WRF (resolution: $18 \mathrm{~km}$ ) for the convective event TS1 at 15 UTC (10 LT).

For the convective event TS1 at 16 UTC (11 LT), Figure 12b shows the resulting Morlet CWT for $w_{b p}$ ZP for the IGW generated around the station of Rio Branco-Brazil. Between the longitudes $64^{\circ} \mathrm{W}$ and $60^{\circ} \mathrm{W}$, two clear enhancements were observed, corresponding to wave signatures peaking at $k_{h}=2 \pi / \lambda_{h} \sim 0.062 \mathrm{rad} \mathrm{km}^{-1}$ and $0.031 \mathrm{rad} \mathrm{km}^{-1}\left(\lambda_{h}=100\right.$ and $200 \mathrm{~km}$, respectively). Moreover, between the longitudes $70^{\circ} \mathrm{W}$ and $64^{\circ} \mathrm{W}$, two enhancements were also observed, corresponding to wave signatures peaking at $k_{h}=2 \pi / \lambda_{h} \sim 0.013 \mathrm{rad} \mathrm{km}^{-1}$ and $\mathrm{rad} \mathrm{km}^{-1}$ ( $\lambda_{h}=200$ and $500 \mathrm{~km}$, respectively). Figure 12a shows the mean zonal variability of $w_{b p}$ between the horizontal strip showed in Figure 11a at $600 \mathrm{hPa}$ at 1530, 1545, 16, 1615 and 1630 UTC $(1030,1045,11,1115$ and 1130 LT). The sloping line in red connects the crests of the carrier wave at various times. The slope of this line is proportional to the speed of the crests. The phase velocity of the carrier wave is approximately equal to $152 \mathrm{~km} \mathrm{~h}^{-1}\left(42.2 \mathrm{~m} \mathrm{~s}^{-1}\right)$. The patterns of vertical velocity $\left(\mathrm{m} \mathrm{s}^{-1}\right)$ at $450 \mathrm{hPa}$ associated with the propagation of IGWs, are shown in Figure 12c, d at 1545 UTC (1045 LT) and 2015 UTC (1515 LT), respectively. Throughout their life cycle, the wave fronts propagate mainly north-westerly along the eastern side of the Andes. At 1545 UTC (1045 LT) the wave fronts were located around the location of the station of Rio Branco-Brazil. At a later time 2045 UTC (1545 LT), the wave fronts arrived at the east region of the Mantaro valley $\left(12.05^{\circ} \mathrm{S}, 75.32^{\circ} \mathrm{W}\right)$. These wave 
fronts can intensify the transport of momentum and moisture from the SALLJ to the inside regions of the Andes. The simulation results show that the moisture transport toward the interior of the Andes is intensified by the arriving of the IGW generated in the previous hour over the Amazon basin (Figure 8).
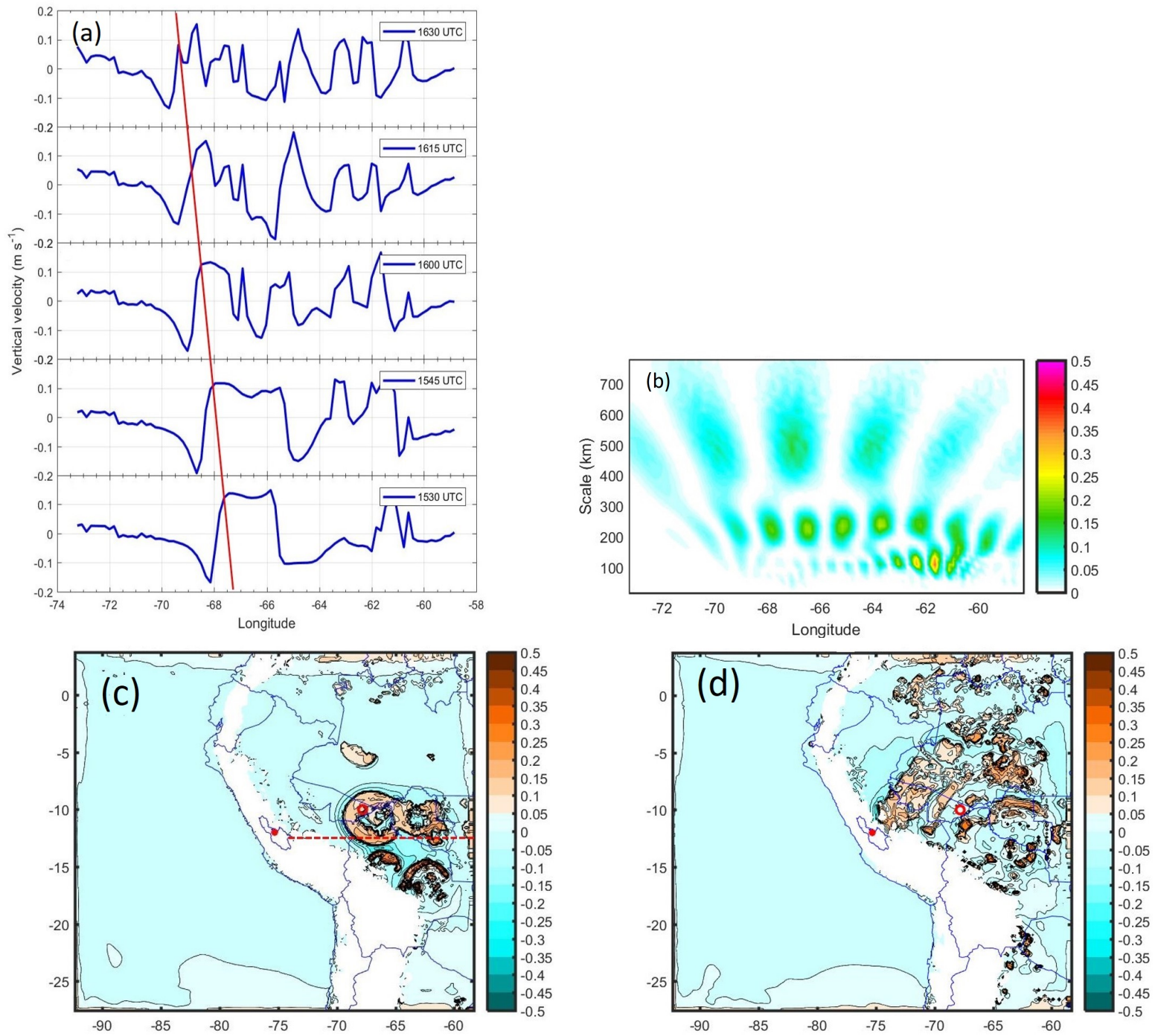

Figure 12. (a) Zonal and time variability of vertical wind speed $\left(w_{b p}, \mathrm{~m} \mathrm{~s}^{-1}\right)$ at $600 \mathrm{hPa}$. The data were obtained from the model WRF (resolution: $18 \mathrm{~km}$ ) for the convective event TS1 at 1530, 1545, 16, 1615, 1630 UTC $\left(1030,1045,11,1115,1145\right.$ LT). (b) Morlet CWT for $\left(w_{b p}, \mathrm{~m} \mathrm{~s}^{-1}\right)$ at 16 UTC (11 LT); Horizontal section of vertical velocity at $450 \mathrm{hPa}$ for the convective event TS1 at (c) 1545 UTC (1045 LT) and (d) 2015 UTC (1515 LT). The full circle indicates the location of the Huancayo observatory $\left(12.05^{\circ} \mathrm{S}, 75.32^{\circ} \mathrm{W}\right.$, $3313 \mathrm{~m}$ a.s.l.).

In contrast to the previous case (TS1), the simulation results for the TS2 and TS3 events do not present the presence of IGW in the Amazon basin, probably because this region is less conditionally unstable with values of CAPE close to $1536.7 \mathrm{~J} \mathrm{~kg}^{-1}$ for TS2 (Figure $5 \mathrm{~b}$ ) and $1617.4 \mathrm{~J} \mathrm{~kg}^{-1}$ for TS3 (Figure $5 \mathrm{c}$ ) and values of CIN close to $-8.9 \mathrm{~J} \mathrm{~kg}^{-1}$ for TS2 (Figure $5 \mathrm{~b}$ ) and $-83.2 \mathrm{~J} \mathrm{~kg}^{-1}$ for TS3 (Figure $5 \mathrm{c}$ ). 


\subsubsection{Local Processes}

For the TS1 event, during the intrusion of the sea-breeze circulation coupling with high and mid-level westerly circulations, convection is triggering by orographic lifting over the western slope of the Andes which generates deep $\mathrm{Cb}$ clouds that propagate north-easterly (Figure 9e). The simulation results show that most of these $\mathrm{Cb}$ clouds dissipate in the frontier of the Mantaro valley and generate stratiform precipitation over the Mantaro valley during their dissipating stages. However, when the mixing north-westerly flow meets with the south-easterly flow coming from the Amazon basin, then a set of deep $\mathrm{Cb}$ clouds develop in the middle of the Mantaro valley.

Figure $13 \mathrm{c}$ shows the time series of vertical velocity obtained with the BLTR radar (red line) and the ARPS model (blue line) at $6000 \mathrm{~m}$ high. At this altitude, two well-defined vertical velocity peaks were observed, the first one around 2215 UTC (1715 LT) and the second one around 0100 UTC (20 LT). Comparison between ARPS model output and observations of the BLTR radar reveals that the model realistically simulates the vertical velocity peaks, but the model results overestimate the values in $2 \mathrm{~m} \mathrm{~s}^{-1}$ for the second peak. Moreover, time series of horizontal wind direction (BLTR radar) measured from the north at $6000 \mathrm{~m}$ high during the TS1 event is shown in Figure 13d. During the occurrence of the vertical velocity peaks, the horizontal wind oscillates from the north or northwest $\left(\sim 0^{\circ}\right)$ to the south and southeast $\left(\sim 180^{\circ}\right)$ directions. This is an evidence that there is a convergence of north-westerly and south-easterly flows during the occurrence of the storm. After the dissipation of the storm, approximately at 0215 UTC (2115 LT) on 30 December 2015, the wind direction remains almost constant, flowing north-westerly ( $\sim 130$ degrees). Comparison between ARPS model output and observations of the BLTR radar reveals that the model simulates partially the tendency of the horizontal wind direction.

Further details of the convergence between moisture fluxes over the Mantaro valley are displayed in Figure 14a, which shows the flow of water vapor for the resolution of $0.5 \mathrm{~km}$ at 0115 UTC (2015 LT) of 30 December 2015. A strong north-westerly moisture flow was observed with intensities close to $40 \mathrm{~kg} \mathrm{~m}^{-1} \mathrm{~s}^{-1}$. This flow collides with other weaker south-easterly moisture flow with the same intensity around the location of the Huancayo observatory. Moreover, it is possible to observe another region of strong convergence in the south-west region of the Mantaro valley, with moisture fluxes close to $80 \mathrm{~kg} \mathrm{~m}^{-1} \mathrm{~s}^{-1}$. It is important to note that the moisture fluxes follow trajectories following the topographic features for the resolution of $0.5 \mathrm{~km}$ (Figure 2d).

The strong low-level convergence generated by the collision of these moisture fluxes produces deep convective clouds, as it was observed by the combined issosurface $\left(0.5 \mathrm{~g} \mathrm{~kg}^{-1}\right)$ of cloud, ice, rain, and hail mixing ratios (Figure 14b) at 0115 UTC (2015 LT) of 30 December 2015. The vertical cross-section of mean divergence flux across the longitude and latitude of the Huancayo observatory are shown in Figure $14 \mathrm{c}, \mathrm{d}$, respectively. The maximum and minimum values of divergence flux associated with updrafts and downdrafts of the thunderstorm are reached at an approximate altitude of $8 \mathrm{~km}$ from the surface with values close to $\pm 8.0 \times 10^{-3} \mathrm{~s}^{-1}$.

At 0115 UTC (2015 LT), the updraft velocities associated with the convergence flux, increased rapidly with height within the cloud, which consists entirely of a warm buoyant plume of rising air. Across the $\mathrm{Cb}$ clouds, the tops of the cloud are found at increasingly higher altitudes, since the new updrafts form systematically on the developing side of the cloud. The simulation results show that the top of the cloud moves upward with a velocity of the order of $10 \mathrm{~m} \mathrm{~s}^{-1}$ at $11 \mathrm{~km}$ high as it is observed in Figure 14e,f. The simulation results generated hail mixing ratio of the order of $1.5 \mathrm{~g} \mathrm{~kg}^{-1}$ at $10 \mathrm{~km}$ high (Figure $13 \mathrm{a}, \mathrm{b}$ ), very close to the isotherm of $-40{ }^{\circ} \mathrm{C}$ where the Bergeron microphysical process is very efficient in producing ice and energy by the release of latent heat. The hail mixing ratio reaches the surface and its value decreases by $0.3 \mathrm{~g} \mathrm{~kg}^{-1}$. 
During the strong convergence over the Huancayo observatory at 0115 UTC (2015 LT), the equivalent potential temperature $\left(\theta_{e}\right)$ exhibits a conditionally unstable layer from the surface $(3 \mathrm{~km})$ up to $5 \mathrm{~km}$ high, with values between $342 \mathrm{~K}$ up to $338 \mathrm{~K}$ as it was observed in the contours of $\theta_{e}$ along the longitude and latitude of the Huancayo observatory (Figure 14c,d). Consistent with the cooler troposphere, because the isotherm of $0{ }^{\circ} \mathrm{C}$ is very close to the surface (Figure 15c), the higher values of $\theta_{e}$ near the surface are produced by higher values of mixing ratio $\left(\sim 8 \mathrm{~g} \mathrm{~kg}^{-1}\right)$ near the surface (Figure 13a,b). In fact, early in the morning, above the Huancayo observatory, the mixing ratio had values close to $5 \mathrm{~g} \mathrm{~kg}^{-1}$ (not shown), but during the afternoon and early night, the flows around the Mantaro valley transport significant amounts of water vapor within the convective boundary layer (CBL), increasing the mixing ratio up to values higher than $8 \mathrm{~g} \mathrm{~kg}^{-1}$.

Figure 15a,b show the mean reflectivity values along longitude and latitude respectively. The maximum values of simulated reflectivity are found around $10 \mathrm{~km}$ high, with maximum values close to $45 \mathrm{dBZ}$ around the region where maximum hail mixing rations are found (Figure 13a,b). Figure 15c shows the time series of mean reflectivity (dBZ), reflectivity obtained with the algorithm of Kessler [68], above the Huancayo observatory. A similar pattern of the observed radar reflectivity from MIRA-35c (Figure 6a) was observed, except between 2330 UTC (1830 LT) and 0100 UTC (20 LT).
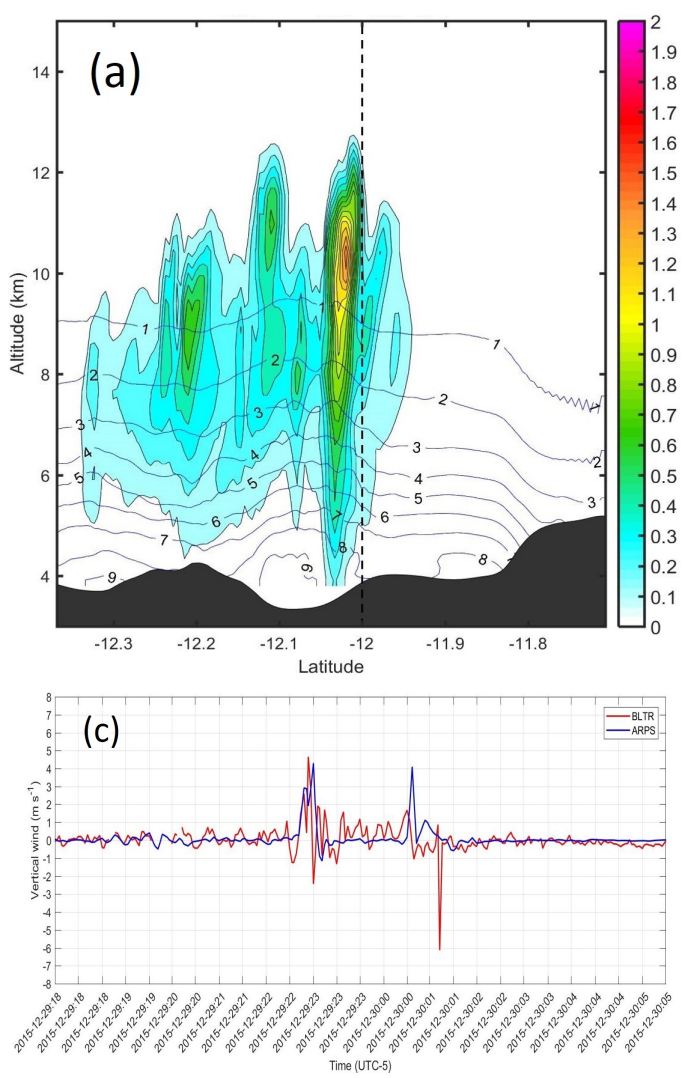
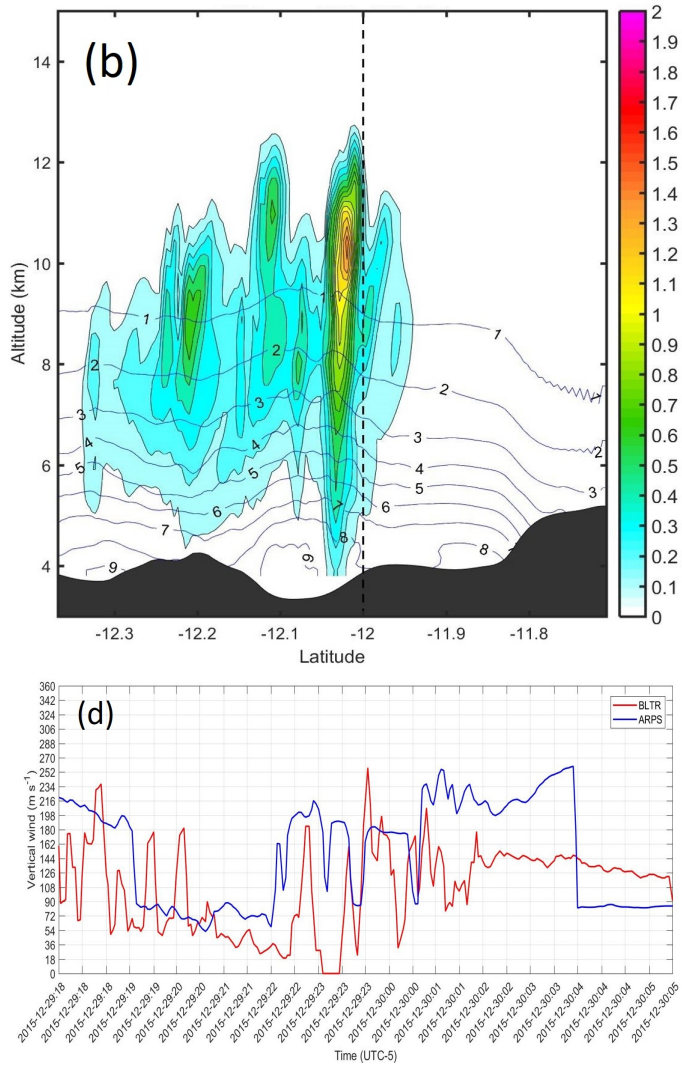

Figure 13. Vertical cross section of hail mixing ratio $\left(\mathrm{g} \mathrm{kg}^{-1}\right)$ along (a) longitude and (b) latitude of the Huancayo observatory showed with vertical dotted lines. All fields were obtained from the ARPS model (resolution: $0.5 \mathrm{~km}$ ) at 0115 UTC (2015 LT) of 30 December, 2015 (TS1); (c) Time series of vertical wind speed $\left(\mathrm{m} \mathrm{s}^{-1}\right.$ ) obtained with the BLTR radar (red line) and the ARPS model (blue line) at $3000 \mathrm{~m}$ high from the surface for the TS1 event; (d) Time series of wind direction at $6000 \mathrm{~m}$ high from the surface during the TS1 event obtained with the BLTR radar (red line) and the ARPS model (blue line) at $3000 \mathrm{~m}$ high from the surface for the TS1 event. 

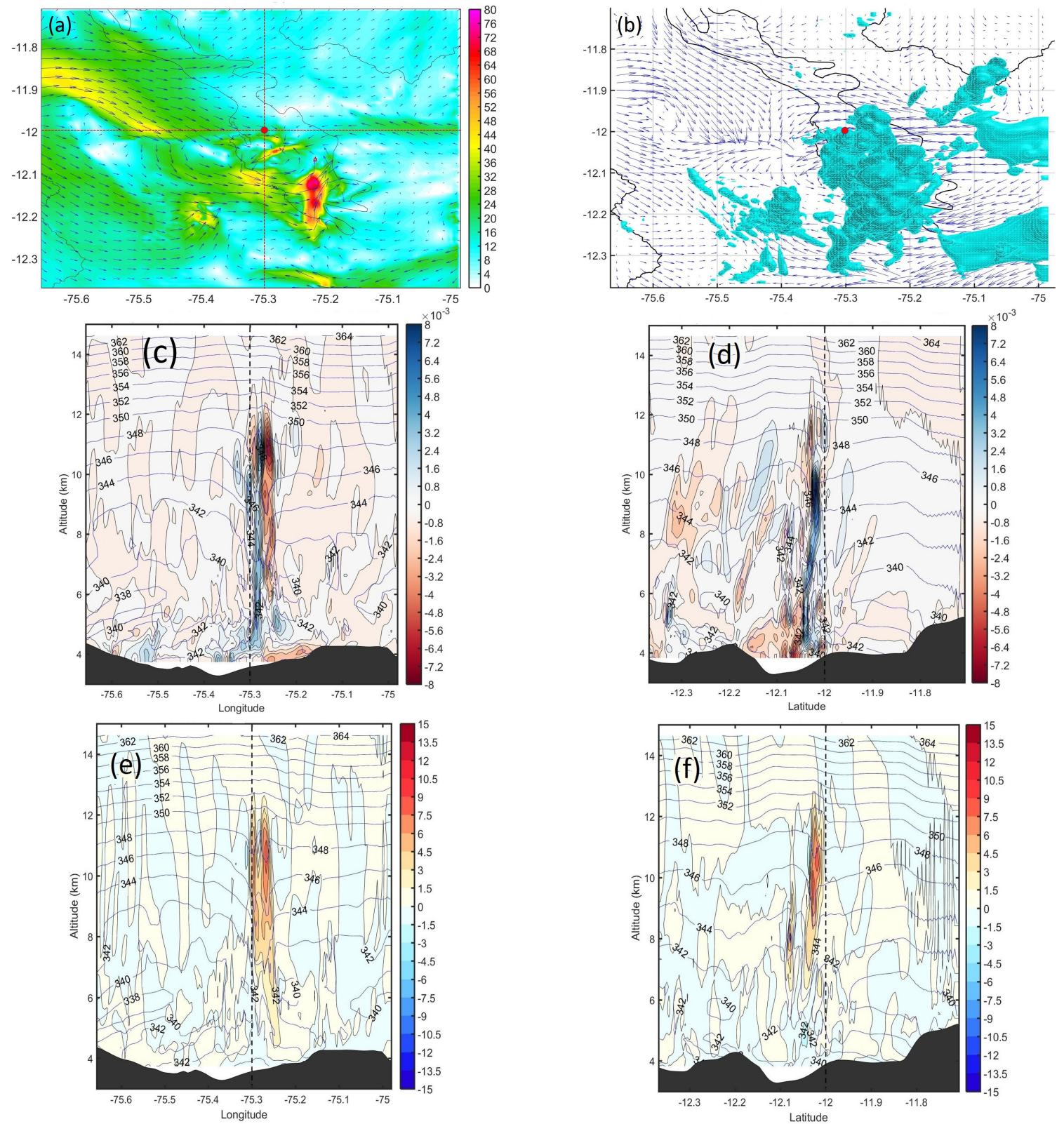

Figure 14. (a) Horizontal flow of vertically integrated total column of water vapor flux $\left(\mathrm{kg} \mathrm{m}^{-1} \mathrm{~s}^{-1}\right)$; (b) Horizontal flow of surface wind $\left(\mathrm{m} \mathrm{s}^{-1}\right)$ with combined isosurface of cloud, ice, rain and hail mixing ratios $\left(q_{c}+q_{i}+q_{s}+q_{h}\right)\left(0.5 \mathrm{~g} \mathrm{~kg}^{-1}\right)$. Vertical cross section of mean divergence fluxes $\left(\mathrm{s}^{-1}\right)(\mathbf{c}, \mathbf{d})$ and mean vertical velocities $\left(\mathrm{m} \mathrm{s}^{-1}\right)(\mathbf{e}, \mathbf{f})$ along longitude and latitude of the Huancayo observatory showed with dotted horizontal lines in (a). All fields were obtained from the ARPS model (resolution: $0.5 \mathrm{~km}$ ) at 0115 UTC (2015 LT) of 30 December, 2015.

For the TS2 and TS3 events, the patterns of equivalent potential temperature $\left(\theta_{e}\right)$ and water vapor mixing ratio indicate the presence of an atmosphere conditionally unstable from the surface up to $5 \mathrm{~km}$ high with values of $\theta_{e}$ between $342 \mathrm{~K}$ and $338 \mathrm{~K}$ and with values of water vapor mixing ratio close to $9 \mathrm{~g} \mathrm{~kg}^{-1}$ near to the surface. As in the previous case (TS1), the simulation results for the inner domain (resolution: $0.5 \mathrm{~km}$ ) generate vertical velocity peaks around the location of the Huancayo observatory. For the TS2 event, between 2200 UTC (17 LT) and 0030 UTC (1930 LT) with values between 3 and $5 \mathrm{~m} \mathrm{~s}^{-1}$ at altitudes 
between 6 and $8 \mathrm{~km}$. For the TS3 event, between 2200 UTC (17 LT) and 0030 UTC (1930 LT) with values between 3 and $5 \mathrm{~m} \mathrm{~s}^{-1}$ at altitudes between 6 and $8 \mathrm{~km}$. These updrafts generate reflectivity fields using the algorithm of Kessler [68] with values close to $30 \mathrm{dBZ}$ (TS2: Figure 16a) and $40 \mathrm{dBz}$ (TS3: Figure 16b). The simulation results reproduced the reflectivity patterns measured by the cloud radar MIRA-35c for the TS2 (Figure 6b) and TS3 (Figure 6c) events but also generated reflectivity fields in times that MIRA-35c does not observe. The discussions of these results are presented in Section 5.
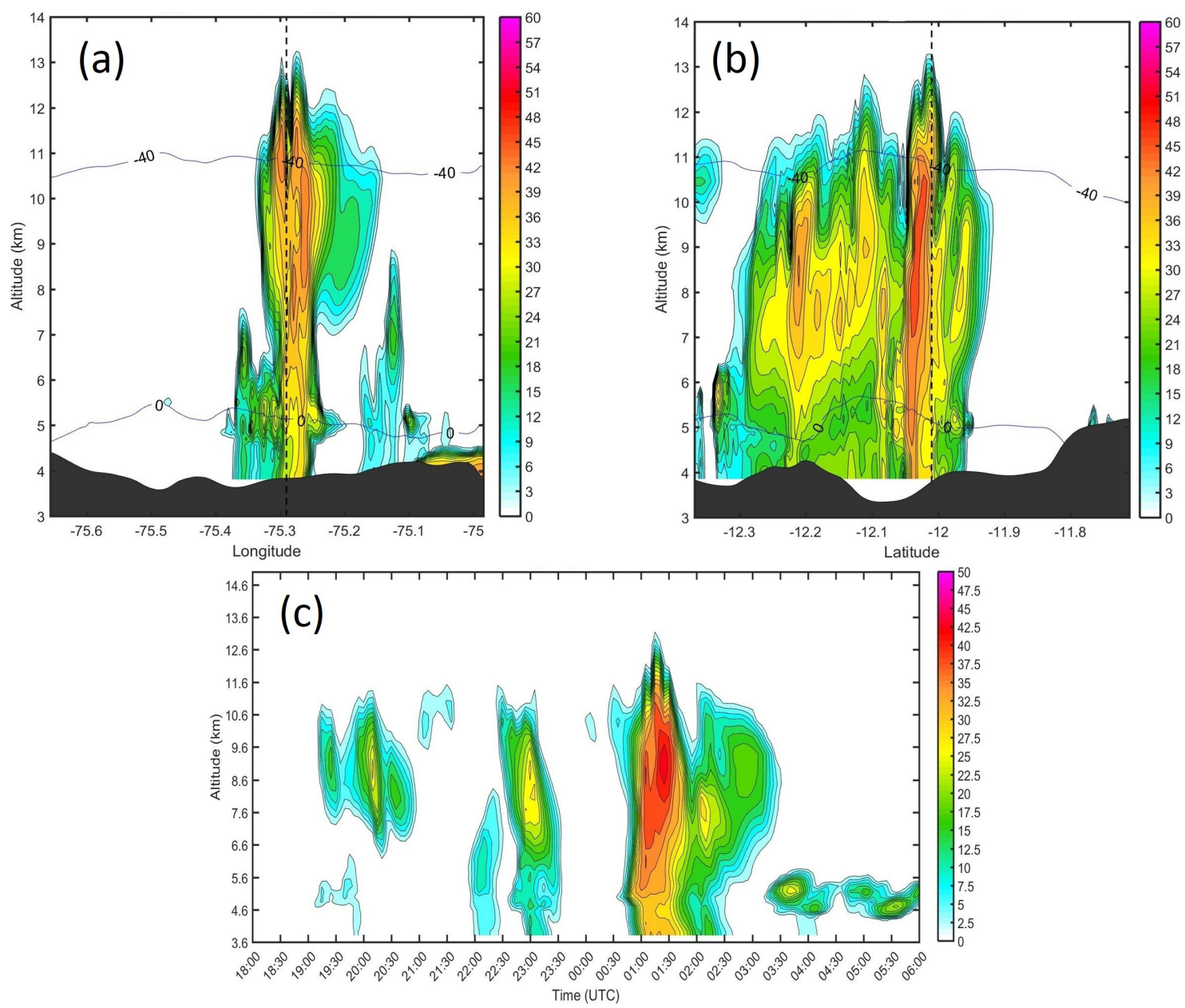

Figure 15. Mean reflectivity (dBZ) along (a) longitude and (b) latitude obtained from the ARPS model (resolution: $0.5 \mathrm{~km}$ ) at 0115 UTC (2015 LT) of 30 December, 2015. Black dotted lines indicate the location of the Huancayo observatory (Figure 1a); (c) Time series of mean reflectivity (dBZ) above the Huancayo observatory (Figure 1a) obtained from the ARPS model (resolution: $0.5 \mathrm{~km}$ ) using the algorithm of Kessler [68] which combines the mixing ratios of all hydrometeors. The mean values were obtained inside a square of $1 \mathrm{~km}$ around the Huancayo observatory. 

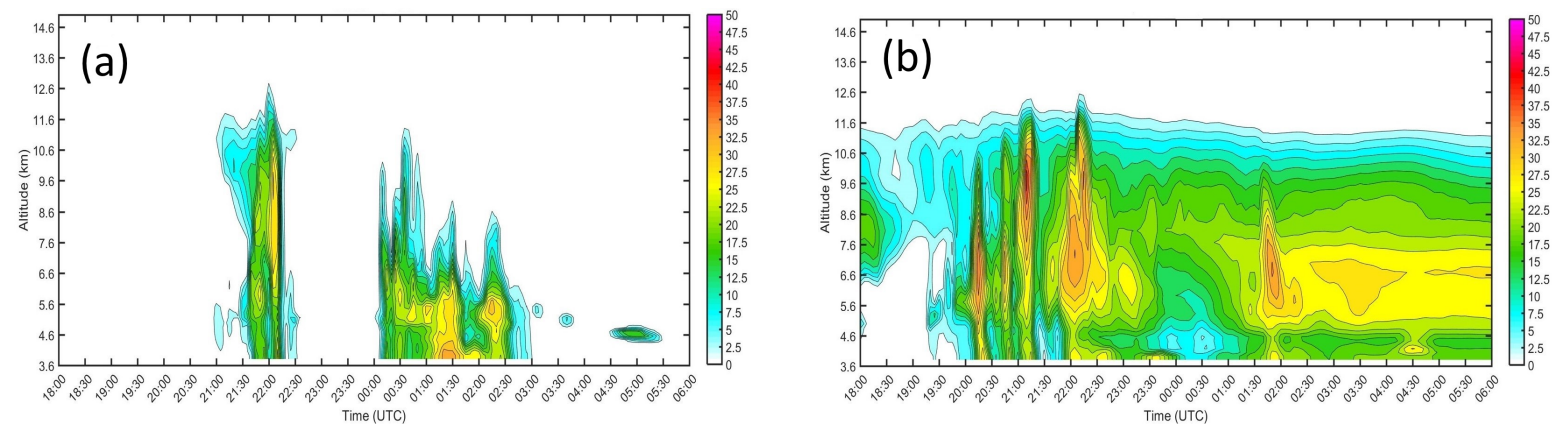

Figure 16. Time series of mean reflectivity (dBZ) over the Huancayo observatory obtained from the ARPS model (resolution: $0.5 \mathrm{~km}$ ) for the (a) TS2 event and (b) TS3 event.

\section{Discussions}

\subsection{Large Scale Processes}

The South-east Pacific Subtropical Anticyclone (SPSA) is the dominant forcing of the subtropical gyre. At the seasonal scale, in the austral summer (December-March), the SPSA is more intense off the coast of central-southern Chile $\left(35^{\circ} \mathrm{S}\right)$. In the winter season, it is more intense off the coast of northern Chile $\left(30^{\circ} \mathrm{S}\right)[69]$. Due to the subsidence that it generates, the SPSA is the primary cause of the arid, stable conditions along northern Chile and the southern Peru coast, extending inland over the western slope of the Andes [70]. At the inter-annual scale, the intensity of the SPSA diminishes (increases) during the warm (cold) phase of the El Niño Southern oscillation (ENSO). For the three TSs analyzed here, it was observed that the location of the SPSA is between $35^{\circ} \mathrm{S}$ and $40^{\circ} \mathrm{S}$ and the atmospheric pressure around the Mantaro valley $\left(12^{\circ} \mathrm{S}\right)$ has relatively low values between 1008 and $1014 \mathrm{hPa}$ that diminishes the subsidence effect over the coast pacific and favors the intrusion of the sea-breeze at the west side of the Andes.

The SALLJ is a component of the southern monsoon system, which transports moisture from the trade winds and the Amazon basin to the Paraná-Plata basin, affecting the weather and climate of the eastern region of the Andes Cordillera (Figure 1b). The SALLJ events can influence, through variations in moisture transport, the severe weather conditions associated with large convective clouds throughout the eastern fringe of the Andes mountain range, which, in turn, can generate heavy storms and floods [71,72]. For the three TSs analyzed here, it was observed a well-defined SALLJ flowing south-easterly at $850 \mathrm{hPa}$ at 1800 UTC. The trade winds are blocked by the Andes which transport warm moisture winds to the east side of the Mantaro valley (Figure 1b). This synoptic configuration of the SALLJ is similar with that found by the study of Romatschke [12] for extreme convection in the northern foothill of the central Andes, where convection is probably triggered as the SALLJ is lifted thought the foothills.

For the three TSs analyzed here, the upper $(300-200 \mathrm{hPa})$ and mid-level $(600 \mathrm{hPa})$ circulations at the east side of the central Andes of Peru present a strong south-westerly (TS1), westerly (TS2) and north-westerly (TS3) circulations. It has been established that the strengthening and displacement southward of the $\mathrm{BH}$ is favored by the occurrence of rainfall in the central Andes [73]. The south-eastward displacement of the BH-NL system, apparently is caused by the intrusion of westerly circulations. This atmospheric configuration differs from the conditions of dry and wet spells found in the central Andes $[16,17,19]$ which are associated with westerly (dry) and easterly (wet) wind anomalies. The regional processes during the occurrence of the TSs are analyzed in Section 5.2.

\subsection{Regional Scale Processes}

In South America, various studies have demonstrated that the dynamics of rainfall in coastal areas can be influenced by the land sea-breeze circulation [74,75]. In the west coast of South America, it was 
found that precipitation formation due to the daily sea breeze is favored when anomalous westerly winds predominated in the lower troposphere [76]. Moreover, when a coupling exists between the thermally induced sea breeze and up-slope wind systems, an additional intensification of deep convection and a propagation of the sea breeze front towards the Andes is observed at times $[77,78]$. The coupling between a diurnal sea-land breeze system with thermally driven upslope winds has been identified as the main factor in the formation and dynamics of heavy precipitation in Ecuador and northern Peru during the ENSO of 1991/92 [79]. They also show that these systems can interact with the opposite mid and upper-level trades, which transport remainders of cirrus shields from the Amazon to the coastal plain and intensify deep convection.

For the three TSs analyzed here, the simulation results show the intrusion of the sea-breeze along the Pacific Coast of Peru started between 1500 UTC (10 LT) and 1600 UTC (11 LT). Next, a large band of cloudiness at both sides of the Andes was observed, which is an evidence that the central Andes receive precipitation generated by convection that develops over the mountain range. At the west side of the Andes, the band of cloudiness is caused by the intrusion of the sea-breeze circulation toward the Andes which is intensified by the westerly flow at the mid and upper levels and thermally driven up-slope winds at low levels of the atmosphere [78,79]. At the east side of the Andes, the cloudiness is caused by the transport of moisture flux from the SALLJ $[61,80]$.

It was proposed that elevated plateau surfaces, such as the one located in the central Andes around the Mantaro valley, are warmer in spring and summer seasons than the adjacent free air, as a result of the altitudinal increase in solar radiation and the relative constancy of the effective infrared radiation with height, the plateaus can induce a variety of thermally forced flows because the solar heating generates a convective boundary layer above the plateau and the low terrain. The excess of temperature in the boundary layer of the plateau with respect to the atmosphere at the same height above the lowlands induces changes of temperature and pressure at the passes which are regions with gentle slopes at both sides of the Mantaro valley [81].

For the three TSs analyzed here, the simulation results show two thermally direct circulations coming from the Amazon basin coupling with mid and upper level circulations and channelized by the passes at east side of the Andes. The first one appears at the north-west side and the second at the south-east side of the Mantaro valley. These moisture fluxes interact with the moisture flux coming from the sea-breeze circulation and create a region of strong deep convection in the center of the Mantaro valley close to the location of the Huancayo observatory. After the intrusion of the moisture flux coming from the sea-breeze circulation, the moisture fluxes come from the SALLJ returns to their initial states. The importance of the sea-breeze in the development of convection agrees with previous studies that found a coupling between the thermally induced sea breeze and up-slope wind systems that favor the propagation of the sea-breeze front toward the Andes in Ecuador and northern Peru [77,78]. These conditions are similar to those found in the region of Southern Peru, where the relative maximum precipitation in the highlands is associated with the convergence of north-westerly and south-easterly flows coming from SALLJ and the presence of a local thermally-driven upslope flow coming from the Pacific Ocean [14]. The local processes during the occurrence of the TSs are analyzed in Section 5.3.

\subsection{Local Scale Processes}

It has been identified for the South-American altiplano that the near-surface specific humidity reach values close to $8 \mathrm{~g} \mathrm{~kg}^{-1}$ for days with rainy episodes [16]. For the three TSs analyzed here, the patterns of equivalent potential temperature $\left(\theta_{e}\right)$ and water vapor mixing ratio indicate the presence of a conditionally unstable atmosphere from the surface up to $5 \mathrm{~km}$ high, approximately, with values of $\theta_{e}$ between $342 \mathrm{~K}$ and $338 \mathrm{~K}$ and with values of water vapor mixing ratio between $8 \mathrm{~g} \mathrm{~kg}^{-1}$ and $9 \mathrm{~g} \mathrm{~kg}^{-1}$. 
These unstable conditions favor the generation of updrafts velocities with values close to $10 \mathrm{~m} \mathrm{~s}^{-1}$ that transport moisture from the surface up to $11 \mathrm{~km}$ high. These strong updraft velocities form $\mathrm{Cb}$ clouds favor high condensation rates that generate copious super-cooled water which are collected by ice particles to produce the graupel [82]. The updraft processes continue above the isotherm of $0{ }^{\circ} \mathrm{C}$ and convert graupel particles into hailstones, which become adequately big to fall over the ground.

\section{Conclusions}

The aim of the present study is to obtain certain insights related to the possible trigger mechanisms and moisture sources at different atmospheric scales of three severe TSs identified in the Mantaro valley during the spring-summer season (2015-2016). We have stressed that all results are based on a very small sample of in-situ data, remote sensing estimations and the results of high resolution numerical simulations. Therefore, other studies with a larger set of observations of thermal circulations from the east and west sides of the Andes would be necessary to verify the results obtained in the present contribution. Taking into account these considerations, we conclude the following:

The atmospheric conditions for the three TSs are different from the conditions that characterize dry and wet spells previously identified in the central Andes. These results highlighted that the problem of understanding extreme convective processes in the atmosphere is distinct from the explaining patterns and amounts of precipitation. These TSs are associated with a south-eastern displacement and weakening of the BH-NL system and an intrusion of strong south-westerly (TS1), westerly (TS2), and north-westerly circulations (TS3) at upper $(300 \mathrm{hPa})$ and $\mathrm{mid}(500 \mathrm{hPa})$ levels of the atmosphere along the west side of the Andes Cordillera. Moreover, the southern displacement of the SPSA up to latitudes higher than $35^{\circ} \mathrm{S}$ favors the intrusion of the sea-breeze into the continent. For the TS1 event, the simulation results indicated the presence of IGW in the Amazon basin, apparently generated by a geostrophic adjustment process caused by the superposition of cold air advection at upper levels (westerly winds at $300 \mathrm{hPa}$ ) and warm and moist air advection at the low levels (north westerly winds from SALLJ). The interaction between advection and adjustment processes associated with the jet streams occurs in a conditionally unstable region where the air is nearly saturated. These conditions cause the development of non-thermal wind and vertical circulation that generate an unstable IGW, which transport energy and moisture into the central Andes plateau which could intensify the TSs above the Mantaro valley.

At the west side of the Andes, the simulation results show that these westerly circulations at high and mid-levels are coupled with the sea-breeze front that intrudes into the continent around 1600 UTC and propagates through the passes along the west side of the Andes, transporting moisture into the central Andes and generating topographic convection. At the east side of the Andes, there is a significant moisture flux associated with the SALLJ across the latitude of the Mantaro valley $\left(12^{\circ} \mathrm{S}\right)$. In the hours prior to the occurrence of the TSs, the simulation results show the presence of an important moisture flux coming from the SALLJ, flowing through the passes located at the east side of the Andes. The first moisture flux is located at the north-east region of the Mantaro valley along the so-called Blue cordillera which transports moisture into the plateau up to reach the coastal region of Peru. The second moisture flux is located at the south-east region of the Mantaro valley. Probably, these moisture fluxes are steered by a combination of thermal local conditions and of anticyclone circulations at the level of the plateau around the Mantaro valley $(600 \mathrm{hPa})$.

During late afternoon and early night, these moisture fluxes coming from the west and east sides of the Andes collide into the plateau around the Mantaro valley and generate two combined fluxes: one from the north-west and the other from the south-east sides of the Mantaro valley. Later on, the collision of these moisture fluxes that flow in opposite directions generated regions of strong moisture convergence and vertical velocities that triggered a set of multicell TSs. These regions of strong moisture convergence remain 
until the sea-breeze front coupled with westerly winds cease to intrude into the central Andes around the Mantaro valley. At local scale, the simulation results indicate that there exists low-level conditional instability with strong negative slopes of potential equivalent temperature in the previous hours and during the occurrence of the thunderstorms above the Mantaro valley, probably caused by the combined effect of the intense solar heating of the surface and the moisture contrast between the air within the local boundary layer and the air aloft. Moreover, the near surface specific humidity reaches high values around $8 \mathrm{~g} \mathrm{~kg}^{-1}$, yielding saturation of near-surface air parcels during the development of TSs.

Author Contributions: For the present work, the contributions were distributed as follows: "conceptualization, J.L.F.R. and A.S.M.A.; methodology, J.L.F.R. and D.M.C.; software, A.S.M.A. and J.L.F.R.; validation, J.L.F.R., A.S.M.A. and S.K.; formal analysis, J.L.F.R. and S.K.; investigation, J.L.F.R., S.K. and D.M.C.; resources, E.V.P., A.S.M.A. and J.L.F.R.; data curation, J.L.F.R. and E.V.P.; writing — original draft preparation, J.L.F.R.; writing—review and editing, José Luis Flores Rojas; visualization, J.L.F.R. and E.V.P.; supervision, A.S.M.A. and D.M.C.; project administration, F.Y.SV.; funding acquisition, F.Y.SV.".

Funding: This research was funded by the "Consejo Nacional de Ciencia y Tecnologia" (CONCYTEC) grant number 010-2017-FONDECYT and by the "INNOVATE PERU" grant number 400-PNIC-2015.

Acknowledgments: This work was done using computational resources, HPC-Linux-Cluster, from Laboratorio de Dinámica de Fluidos Geofísicos Computacionales at Instituto Geofísico del Perú (grants 101-2014-FONDECYT, SPIRALES2012 IRD-IGP, Manglares IGP-IDRC, PP068 program). We also thank Ing. Luis Suárez Salas and Manuel Piñas Laura for their help with the maintenance of the equipment and for the data process.

Conflicts of Interest: The authors declare no conflict of interest.

\section{Abbreviations}

The following abbreviations are used in this manuscript:

$\begin{array}{ll}\text { ARPS } & \text { Advance Regional Prediction system } \\ \text { BLTR } & \text { Boundary Layer Tropospheric Radar } \\ \text { BH-LN } & \text { Bolivian high - North east low system } \\ \text { Cb } & \text { Cumulonimbus } \\ \text { CAPE } & \text { Convective available potential energy } \\ \text { CIN } & \text { Convective inhibition energy } \\ \text { ECMWF } & \text { European Center for Medium-Range Weather Forecasts } \\ \text { ENSO } & \text { El Niño Southern oscillation } \\ \text { GPM } & \text { Global Precipitation Measurement } \\ \text { GFS } & \text { Global Forecast System } \\ \text { IGW } & \text { Inertial gravity wave } \\ \text { MIRA-35c } & \text { Compact Meteorological Ka-Band Cloud Radar } \\ \text { NCA } & \text { Northern Central Andes } \\ \text { NCAR } & \text { National Center for Atmospheric Research } \\ \text { NCEP } & \text { National Centers for Environmental Prediction } \\ \text { RRTM } & \text { Rapid Radiative Transfer Model Longwave } \\ \text { SALLJ } & \text { South American low level jet } \\ \text { SPSA } & \text { South-east Pacific Subtropical Anticyclone } \\ \text { TSs } & \text { Thunderstorms } \\ \text { TRMM } & \text { Tropical Rainfall Measuring Mission } \\ \text { WRF } & \text { Weather Research and Forecasting Model } \\ & \end{array}$




\section{References}

1. Cotton, W.; Bryan, G.; Van Den Heever, S. Storm and Cloud Dynamics, 2nd ed.; International Geophysics Series; Elsevier: London, UK, 2011.

2. Teitelbaum, H.; Le Treut, H.; Moustaqui, M.; Cabrera, G.; Ibañez, G. Deep convection east of the Andes Cordillera: A test case analyses of Airmass origin. Mon. Wea. Rev. 2007, 136, 2201-2209. [CrossRef]

3. Killeen, T.; Douglas, M.; Consiglio, T.; Jorgensen, P.; Mejia, J. Dry spots and wet spots in the Andean hotspot. J. Biogeogr. 2007, 34, 1357-1373. [CrossRef]

4. Kumar, S.; Silva-Vidal, Y.; Moya-Álvarez, A.; Martínez-Castro, D. Effect of the surface wind flow and topography on precipitating cloud systems over the Andes and associated Amazon basin: GPM observations. Atmos. Res. 2019, 193-208. [CrossRef]

5. Andrews, D.; Holton, J.; Leovy, C. Middle Atmosphere Dynamics, 1st ed.; Academic Press: New York, NY, USA, 1987.

6. Nappo, C. An Introduction to Atmospheric Gravity Waves, 1st ed.; International Geophysics Series; Elsevier Science: San Diego, CA, USA, 2002.

7. Fritts, D.; Alexander, M. Gravity wave dynamics and effects in the middle atmosphere. Rev. Geophys. $2003,41$. [CrossRef]

8. Hooke, W. Gravity waves. Mesoscale Meteorology and Forecasting. Am. Meteorol. Soc. 1986, 1, $272-288$.

9. Spiga, A.; Teitelbaum, H.; Zeitlin, V. Identification of the sources of inertia-gravity waves in the Andes Cordillera region. Ann. Geophys. 2008, 26, 2551-2568. [CrossRef]

10. Qiushi, C. The instability of the gravity-inertia wave and its relation to low-level jet and heavy rainfall. J. Meteorol. Soc. Jpn. 1982, 60, 1041-1056.

11. Matsumoto, S.; Ninomiya, K. On the meso-scale and medium-scale structure of cold front and relevant vertical circulation. J. Meteorol. Soc. Jpn 1971, 49, 648-668. [CrossRef]

12. Romatschke, U.; Houze, R., Jr. Extreme Summer Convection in South America. J. Clim. 2010, 23, 3761-3790. [CrossRef]

13. Egger, J.; Blacutt, L.; Ghezzi, F.; Heinrich, R.; Kolb, P.; Lämmlein, S.; Leeb, M.; Mayer, S.; Palenque, E.; Reuder, J.; et al. Diurnal Circulation of the Bolivian Altiplano. Part I: Observations. Mon. Weather Rev. 2005, 133, 911-934. [CrossRef]

14. Junquas, C.; Takahashi, K.; Condom, T.; Espinoza, J.; Chavez, S.; Sicart, J.; Lebel, T. Understanding the influence of orography on the precipitation diurnal cycle and the associated atmospheric processes in the central Andes. Clim. Dyn. 2018, 50, 3995-4017. [CrossRef]

15. Virji, H. A preliminary study of summertime tropospheric circulation patterns overt South America estimated from cloud winds. Mon. Wea. Rev. 1981, 109, 599-612. [CrossRef]

16. Garreaud, R. Multiscale analysis of the summertime precipitation over the central Andes. Mon. Wea. Rev. 1999, 127, 901-921. [CrossRef]

17. Garreaud, R.; Vuille, M.; Clement, A. The climate of the Altiplano: Observed and current conditions and mechanisms of past changes. Palaeogeogr. Paleoclimatol. Palaeoecol. 2003, 194, 5-22. [CrossRef]

18. Falvey, M.; Garreaud, R. Moisture variability over the South American Altiplano during the South American low level jet experiment (SALLJEX) observing season. J. Geophys. Res. 2005, 110, D22105. [CrossRef]

19. Sulca, J.; Vuille, M.; Silva, Y.; Takahashi, K. Teleconnections between the Peruvian Central Andes and Northeast Brazil during extreme rainfall events in Austral summer. J. Hydrometeorol. 2015, 17, 499-515. [CrossRef]

20. Vuille, M.; Keimig, F. Interannual variability of summertime convective cloudiness and precipitation in the central Andes derived from ISCCP-B3 data. J. Clim. 2004, 17, 3334-3348. [CrossRef]

21. Moya-Álvarez, A.; Martínez-Castro, D.; Flores Rojas, J.; Silva Vidal, Y. Sensitivity Study on the Influence of Parameterization Schemes in WRF-ARW Model on Short-and Medium-Range Precipitation Forecasts in the Central Andes of Peru. Adv. Meteorol. 2018, 2018, 1381092. [CrossRef]

22. IGP. Atlas Climático de Precipitación y Temperatura del Aire en la Cuenca del Río Mantaro, 1st ed.; Fondo Editorial CONAM-Instituto Geofísico del Perú: Lima, Peru, 2005; Volume I. 
23. Simões Reboita, M.; Krusche, N.; Ambrizzi, T.; Porfírio da Rocha, R. Entendendo o Tempo e o Clima na América do Sul. Terra Didatica 2012, 8, 34-50. [CrossRef]

24. Drumond, A.; Nieto, R.; Gimeno, L.; Ambrizzi, T. A lagrangian identification of major sources of moisture over Central Brazil and La Plata Basin. J. Geophys. Res. 2008, 113, D14128. [CrossRef]

25. Garreaud, R.; Wallace, J. The diurnal of convective cloudiness over the Americas. Mon. Wea. Rev. 1997, 125, 3157-3171. [CrossRef]

26. Oke, T. Boundary Layer Climates, 2nd ed.; Taylor and Francis Group: London, UK, 1987.

27. Wang, M.; Paegle, J. Impact of analysis uncertainty upon regional atmospheric moisture flux. J. Geophys. Res. 1996, 101, 7291-7303. [CrossRef]

28. Berbery, E.; Collini, E. Springtime Precipitation and Water Vapor Flux over Southeastern South America. Mon. Weather Rev. 1999, 128, 1328-1347. [CrossRef]

29. Trenberth, K. Climate diagnostics from global analyses: Conservation of mass in ECMWF analyses. J. Clim. 1991, 4, 707-722. [CrossRef]

30. Connolley, W.; King, J. Atmospheric water vapour transport to Antarctica inferred from radiosondes. J. R. Meteorol. Soc. 1993, 119, 325-342. [CrossRef]

31. Skamarock, W.C.; Klemp, J.B.; Dudhia, J.; Gill, D.O.; Barker, D.M.; Duda, M.G.; Huang, X.Y.; Wang, W.; Powers, J.G. A Description of the Advanced Research WRF Version 3; National Center For Atmospheric Research, Mesoscale and Microscale Meteorology Division: Boulder, CO, USA, 2008.

32. Xue, M.; Droegmeier, K.; Wong, V. The Advanced Regional Prediction System (ARPS)-A multi-scale nonhydrostatic atmospheric simulation and prediction model. Part I:Model Dynamics and Verification. Meteorol. Atmos. Phys. 2000, 1, 1-45.

33. Lin, Y.L.; Farley, R.D.; Orville, H.D. Bulk Parametrization of the Snow Field in a Cloud Model. J. Clim. Appl. Met. 1983, 22, 1065-1092. [CrossRef]

34. Ek, M.; Mitchell, K.; Lin, Y.; Rogers, E.; Grummann, P.; Koren, V.; Gayno, G.; Tarpley, J. Implementation of Noah land surface model advances in the National Centers for Environmental Prediction operational Mesoscale Eta Model. J. Geophys. Res. 2003, 108, 8851. [CrossRef]

35. Tewari, M.; Chen, F.; Wang, W.; Dudhia, J.; LeMone, M.; Mitchell, K.; Ek, M.; Gayno, G.; Wegiel, J.; Cuenca, R. Implementation and verification of the unified NOAH land surface model in the WRF model. In Proceedings of the 20th Conference on Weather Analysis and Forecasting/16th Conference on Numerical Weather Prediction, Seattle, WA, USA, 10 January 2004.

36. Monin, A.; Obukhov, A. Basic laws of turbulent mixing in the surface layer of the atmosphere. Trans. Geophys. Inst. Akad. Nauk. USSR 1954, 151, 163-187.

37. Grell, G.; Freitas, S. A scale and aerosol aware stochastic convective parameterization for weather and air quality modeling. Atmos. Chem. Phys. 2014, 13, 23845-23893. [CrossRef]

38. Hong, S.; Noh, Y.; Dudhia, J. A new vertical diffusion package with an explicit treatment of entrainment processes. Mon. Weather Rev. 2006, 134, 2318-2341. [CrossRef]

39. Mlawer, E.J.; Taubman, S.J.; Brown, P.D.; Iacono, M.J.; Clough, S.A. Radiative transfer for inhomogeneous atmospheres: RRTM, a validated correlated-k model for the longwave. J. Geophys. Res. 1997, 102, $16663-16682$. [CrossRef]

40. Xue, M.; Droegmeier, K.; Wong, V. The Advanced Regional Prediction System (ARPS)-A multi-scale nonhydrostatic atmospheric simulation and prediction model. Part II: Model physics and applications. Meteorol. Atmos. Phys. 2001, 76, 143-165. [CrossRef]

41. Schultz, P. An explicit cloud physics paramterization for operational numerical weather prediction. Mon. Weather Rev. 1995, 123, 3331-3343. [CrossRef]

42. De la Torre, A.; Alexander, P.; Llamedo, P.; Menéndez, C.; Schmidt, T.; Wickert, J. Gravity waves above the Andes detected from GPS radio occultation temperature profiles: Jet mechanism? Geophys. Res. Lett. 2006, 33, $248-258$. [CrossRef]

43. De la Torre, A.; Hierro, R.; Llamedo, P.; Rolla, A.; Alexander, P. Severe hailstorms near Southern Andes in the presence of mountain waves. Atmos. Res. 2010, 101, 112-123. [CrossRef] 
44. Shutts, G.; Kitchen, M.; Hoare, P. A large amplitude gravity wave in the lower stratosphere detected by radiosonde. Q. J. R. Meteorol. Soc. 1988, 114, 579-594. [CrossRef]

45. Claret, M.; Viúdez, A. Vertical velocity in the interaction between inertia-gravity waves and submesoscale baroclinic vortical structures. J. Geophys. Res. 2010, 115, 2156-2202. [CrossRef]

46. Metek. MIRA-35c System Description; Meteorologische Messtechnik GmbH: Elmshorn, Germany, 2015.

47. Sokol, Z.; Minárová, J.; Novák, P. Classification of Hydrometeors Using Measurements of the Ka-Band Cloud Radar Installed at the Milesovka Mountain (Central Europe). Remote Sens. 2018, 10, 1674. [CrossRef]

48. Scipión, D.; Palmer, R.; Chilson, P.; Fedorovich, E.; Botnick, A. Retrieval of convective boundary layer wind field statistics from radar profiler measurements in conjunction with large eddy simulation. Meteorol. Z. 2009, 18, 175-187. [CrossRef]

49. Scipión, D.; Palmer, R.; Chilson, P.; Fedorovich, E.; Botnick, A. Turbulence kinetic energy and dissipation rate estimated from a virtual wind profiles and verified trhough large eddy simualations. In Proceedings of the 34th AMS Conference on Radar Meteorology, Williamsburg, VA, USA, 5-9 October 2009; pp. 1-14.

50. Prakash, S.; Mitra, A.K.; Pai, D.; AghaKouchak, A. From TRMM to GPM: How well can heavy rainfall be detected from space? Adv. Water Res. 2016, 88, 1-7. [CrossRef]

51. Guo, H.; Chen, S.; Bao, A.; Behrangi, A.; Hong, Y.; Ndayisaba, F.; Hu, J.; Stepanian, P. Early assessment of integrated multi-satellite retrievals for global precipitation measurement over China. Atmos. Res. 2016, 176-177, 121-133. [CrossRef]

52. Ma, Y.; Tang, G.; Long, D.; Yong, B.; Zhong, L.; Wan, W.; Hong, Y. Similarity and error intercomparison of the GPM and its predecessor-TRMM multisatellite precipitation analysis using the best available hourly gauge network over the Tibetan Plateau. Remote Sens. 2016, 8, 569. [CrossRef]

53. Tang, G.; Zeng, Z.; Long, D.; Guo, X.; Yong, B.; Zhang, W.; Hong, Y. Statistical and hydrological comparisons between TRMM and GPM Level-3 products over a midlatitude basin: Is Day-1 IMERG a good successor for TMPA 3B42v7? J. Hydrometeorol. 2016, 17, 121-137. [CrossRef]

54. Chen, $\mathrm{C}$. The convective instability of the inertia wave and physical analysis of the formation of the typhoon in the early stage. Acta Met. Sin. 1964, 34, 433-442.

55. Sharifi, E.; Steinacker, R.; Saghafian, B. Assessment of GPM-IMERG and other precipitation products against gauge data under different topographic and climatic conditions in Iran: Preliminary results. Remote Sens. 2016, 8, 135. [CrossRef]

56. Tan, J.; Petersen, W.; Tokay, A. A novel approach to identify sources of errors in IMERG for GPM ground validation. J. Hydrometeorol. 2016, 17, 2477-2491. [CrossRef]

57. Hobouchian, M.; Salio, P.; García Skabar, Y.; Vila, D.; Garreaud, R. Assessment of satellite precipitation estimates over the slopes of the subtropical Andes. Atmos. Res. 2017, 190, 43-54. [CrossRef]

58. Manz, B.; Páez-Bimos, S.; Horna, N.; Buytaert, W.; Ochoa-Tocachi, B.; Lavado-Casimiro, W.; Willems, B. Comparative Ground Validation of IMERG and TMPA at Variable Spatiotemporal Scales in the Tropical Andes. J. Hydrometeorol. 2017, 18, 2469-2489. [CrossRef]

59. Menzel, W.P.; Purdom, J.F. Introducing GOES-I: The first of a new generation of geostationary operational environmental satellites. Bull. Am. Meteorol. Soc. 1994, 75, 757-781. [CrossRef]

60. Lhermitte, R. Attenuation and Scattering of Millimeter Wavelength Radiation by Clouds and Precipitation. J. Atmos. Ocean. Technol. 1990, 7, 464-479. [CrossRef]

61. Chavez, S.; Takahashi, K. Orographic rainfall hot spots in the Andes-Amazon transition according to the TRMMM precipitation radar and in situ data. J. Geophys. Res. Atmos. 2017, 122, 5870-5882,. [CrossRef]

62. Kalthoff, N.; Bischoff-Gaub, I.; Fiedler, F. Mesoscale wind regimes in Chile at 30. J. Appl. Meteorol. 2002, 41, 953-970. [CrossRef]

63. Garreaud, R. The Andes climate and weather. Adv. Geosci. 2009, 22, 3-11. [CrossRef]

64. Barry, R.G. Mountain Weather and Climate, 3rd ed.; Cambridge, University Press: New York, NY, USA, 2008 ; p. 73.

65. Guest, F.; Reeder, M.; Marks, C.; Karoly, D. Inertia-gravity waves observed in the lower stratosphere over Macquarie Island. J. Atmos. Sci. 2000, 57, 737-752. [CrossRef] 
66. Pavelin, E.; Whiteway, J.A.; Vaughan, G. Observation of gravity wave generation and breaking in the lowermost stratosphere. J. Geophys. Res. 2001, 106, 5173-5180. [CrossRef]

67. Plougonven, R.; Teitelbaum, H.; Zeitlin, V. Inertia gravity wave generation by the tropospheric midlatitude jet as given by the Fronts and Atlantic Storm-Track Experiment radio soundings. J. Geophys. Res. 2003, 108, 4686-4704. [CrossRef]

68. Kessler, E. On the Distribution and Continuity of Water Substance in Atmospheric Circulations. Meteorol. Monogr. $1969,10,1-88$.

69. Ancapichún, S.; Garcés-Vargas, J. Variability of the Southeast Pacific Subtropical Anticyclone and its impact on sea surface temperature off north-central Chile. Cienc. Mar. 2015, 41, 1-20. [CrossRef]

70. Houston, J.; Hartley, A. The central Andean west-slope rain-shadow and its potentical contribution to the origin of hyperaridity in the Atacama Desert. Int. J. Climatol. 2003, 23, 1453-1464. [CrossRef]

71. Marengo, J.; Soares, W.; Saulo, C.; Nicolini, M. Climatology of the Low-Level Jet East of the Andes as Derived from the NCEP-NCAR Reanalyses: Characteristics and Temporal Variability. J. Clim. 2004, 17, $2261-2280$. [CrossRef]

72. Vera, C.; Baez, J.; Douglas, M.; Emmanuel, C.; Marengo, J.; Meitin, J.; Nicolini, M.; Nogues-Paegle, J.; Paegle, J.; Penalba, O.; et al. The South American Low-Level Jet Experiment. Bull. Am. Meteorol. Soc. 2006, 87, 63-77. [CrossRef]

73. Lenters, J.; Cook, K. On the origin of the Bolivian high and related circulation features of the South American climate. J. Atmos. Sci. 1997, 54, 656-677. [CrossRef]

74. Pereira Filho, A.; Barros, M.; Hallak, R.; Gandu, A. Enchentes na região metropilitana de São Paulo: Aspectos de mesoescala e avaliação de impactos. In Proceedings of the XIII Congresso Brasileiro de Meterologia, Fortaleza, CE, USA, 28 August-3 September 2004.

75. Vemado, F.; Pereira Filho, A. Severe weather caused by Heat Island and Sea breeze effects in the Metropolitan Area of São Paulo, Brazil. Adv. Meteorol. 2015, 2016, 8364134. [CrossRef]

76. Fett, R.; Tag, P. Satellite observation and numerical model results of sea breeze effects as applied to the west coast of South America. In Proceedings of the First International conference on Southern Hemisphere Meteorology, São José dos Campos, Brazil, 31 July-6 August 1983; pp. 337-340.

77. Horel, J.; Cornejo-Garrido, A. Convection along the coast of northern Peru during 1983. Mon. Weather Rev. 1986, 114, 2091-2105. [CrossRef]

78. Takahashi, K. The atmospheric circulation associated with the extreme rainfall events in Piura, Peru, during the 1997 and 2002 El niño events. Ann. Geophys. 2004, 22, 3917-3926. [CrossRef]

79. Bendix, J. Precipitation dynamics in Ecuador and northern Peru during the 1991/92 El niño: A remote sensing perspective. Int. J. Remote Sens. 2000, 21, 533-548. [CrossRef]

80. Espinoza, J.; Chavez, S.; Ronchail, J.; Junquas, C.; Takahashi, K.; Lavado, W. Rainfall hotspots over the southern tropical Andes: Spatial distribution, rainfall intensity and relations with large-scale atmospheric circulation. Water Resour. Res. 2015, 51, 1-17. [CrossRef]

81. Flohn, H. Hochgebirge und allgemeine Zirkulation II. Die Gebirge als Warmequellen. Arch. Meteorol. Geophys. Biokl. 1953, A5, 265-279.

82. Houze, R. Cloud Dynamics, 1st ed.; Academic Press: San Diego, CA, USA, 1993.

(C) 2019 by the authors. Licensee MDPI, Basel, Switzerland. This article is an open access article distributed under the terms and conditions of the Creative Commons Attribution (CC BY) license (http:/ / creativecommons.org/licenses/by/4.0/). 